\title{
Eskişehir İl Halk Kütüphanesi Dermesinde Bulunan Resimli Çocuk Kitaplarının Fiziksel ve İçerik Özelliklerinin Ödünç Alınma Üzerinde Etkisi*
}

\author{
The Effect of Physical and Content Characteristics of Illustrated Children's Books in \\ the Eskişehir Provincial Public Library's Collections on Borrowing
}

\author{
Gözde Anıl Yılmaz**(D) ve Bülent Yıımaz**:(D)
}

$\ddot{O} z$

Genellikle çocuk edebiyatı eserleri aracılığıyla yaratılan ve güçlendirilen okuma kültürü, çocukların zihinsel (bilişsel), ruhsal, sosyal, ahlaki, dilsel ve estetik gelişimlerinde önemli işlevlere sahiptir. Çocukların bebeklik dönemlerinden itibaren çocuğa görelik ilkesine uygun nitelikte çocuk kitapları ile karşılaşmaları onların okuma kültürlerini yaşamları boyunca sürecek biçimde sağlam ve sağllklı bir temele oturtacaktır. Halk ve çocuk kütüphaneleri, çocukları çeşitli türde ve çok sayıda çocuk kitabı ile buluşturan toplumsal kuruluşlardır. Ancak bu kütüphanelerin okuma kültürü konusundaki önemli rollerini yerine getirebilmeleri için çocuğa uygun ve nitelikli çocuk kitapları dermesine sahip olmaları gerekmektedir. Amaç: Bu çalışmanın amacl, Eskişehir Il Halk Kütüphanesinin dermesinde yer alan okul öncesi (erken dönem) resimli çocuk kitaplarını fiziksel (dış yapı) ve içerik (içyapı) özellikleri ile çocuğa görelik ilkesi açısından değerlendirerek, bunun ödünç alma üzerine etkilerini ortaya koymaktır. Yöntem: Bu amaç doğrultusunda araştırma kapsamına, Eskişehir Il Halk Kütüphanesi dermesinde bulunan ve 2015-2019 yılları arası yayımlanmış 0-7 yaş arası çocuklara hitap eden basılı Türkçe resimli çocuk kitapları alınmıştır. Araştırmada bu yıllara ait evreni oluşturan 2,197 kitap, 130 kitap ile örneklenmiştir. Betimleme yöntemi ile gerçekleştirilen araştırmada örnekleme alınan resimli çocuk kitaplarının fiziksel ve içerik özellikleriyle çocuğa görelik niteliklerine ait veriler, araştırmacılar tarafindan oluşturulan "Resimli Çocuk Kitaplarını Değerlendirme Formu” aracılığıyla elde edilmiş ve elde edilen veriler ödünç alınma durumlarıyla ilişkilendirilerek değerlendirilmiştir. Bulgular: Çalışmada elde edilen bulgulara göre, Eskişehir Il Halk Kütüphanesindeki resimli çocuk kitaplarının \%60,8'inin yılda ortalama 1-3 kez ödünç alındı̆̆l; kalın karton kapakl kitapların \%56,2 'si yılda ortalama 7 kez ve daha fazla ödünç alınırken, bu oranın ince kartonlu kapă̆a sahip kitaplar için \%5,3 olduğu; özgün çocuk kitaplarının \%81,9'unun, çeviri çocuk kitaplarının ise \%96,6'sının ödünç alındı̆̆l;

\footnotetext{
* Bu makale, 2020 yılında Gözde Anıl Yılmaz tarafından Hacettepe Üniversitesi Sosyal Bilimler Enstitüsü Bilgi ve Belge Yönetimi Anabilim Dalında tamamlanan "Eskişehir İl Halk Kütüphanesi Resimli Çocuk Kitaplarının Değerlendirilmesi” başlıklı yüksek lisans tezine dayanarak hazırlanmıştır.

** Anadolu Üniversitesi Kütüphanesi, Eskişehir, Türkiye. E-posta: gozderdas@gmail.com Anadolu University Library, Eskişehir,Turkey.E-mail: gozderdas@gmail.com

**** Hacettepe Üniversitesi, Bilgi ve Belge Yönetimi Bölümü, Ankara, Türkiye. E-posta: byilmaz963@ gmail.com Hacettepe University, Department of Information Management, Ankara, Turkey. E-mail:

byilmaz963@gmail.com
}

Geliş Tarihi-Received: 21.06.2021

Kabul Tarihi - Accepted: 08.09.2021

Yayımlanma Tarihi - Published: 30.09.2021 
kapă̆ görsel çekiciliği sahip resimli çocuk kitaplarının \%96,6'sı ödünç alınırken, bu oranın kapă̆l görsel açıdan çekici olmayan kitaplar için \%81,7’ye düştügü; çocuğun ilgi ve gereksinimlerine uygun olan kitapların \%94,7'si ödünç alınırken, çocuğun gelişimine uygun olmadiğ belirlenen kitaplarda ödünç alınma oranının \%66,7'ye, kısmen uygun olanlarda ise \%81,2 'ye düştüğ̈̈; çocukta okuma isteği uyandiracak nitelikte olan resimli çocuk kitaplarının $\% 98,2$ 'si, klsmen bu nitelikte olanların \%89,5 ve niteliksiz çocuk kitaplarının da \%72,3'ü yılda en az 1 kez ödünç alındı̆̆ anlaşılmıştır. Sonuç: Eskişehir Il Halk Kütüphanesi dermesinde bulunan resimli çocuk kitaplarının çoğunlukla yılda ortalama 1-3 kez ödünç alındı̆̆l; bu kitaplardaki basım bilgisinin yıllık ödünç alınma sıklıkları üzerinde etkili olmadı̆̆g; kitapların boyutlart ve üzerlerinde hitap ettiği yaş grubu bilgisinin bulunması ile yıllık ödünç alınma sıklıkları arasında istatistiksel açıdan anlamlı bir ilişki bulunmadığı; özgün ya da çeviri olma durumunun ödünç alınma sıklıkları üzerinde etkili olduğu; kapak görsellerinin ilgi çekici olması, kapak resimlerinin içeriği (konuyu) yansıtması ve resimlerin çocuğun öykü oluşturmasına uygun nitelikte olması ile resim ve metin oranı uygunluğunun kitapların ödünç alınmasında etkili olduğu belirlenmiştir. Bulgular ışı̆̆ında, Eskişehir İl Halk Kütüphanesi dermesinde bulunan resimli çocuk kitaplarının çocuğun gelişim düzeyine, ilgi ve gereksinimlerine uygun olmasının ödünç alınma durumları üzerinde olumlu yönde etkili olduğu ve daha çok ödünç alındı̆̆ yönünde sonuca ulaşılmıştır. Çalışmada sunulan bulgu ve sonuçlarla araştırma amacına ulaşmıştır. Özgünlük: Yapılan bu araştırma, halk ve çocuk kütüphanelerinde nitelikli derme geliştirme ve yönetim süreçleri açısından resimli çocuk kitaplarında ödünç almayı etkileyen ve etkilemeyen fiziksel ve içerik unsurlarını gösterdiği için özgündür. Bir halk kütüphanesi dermesinde bulunan çocuk kitaplarının fiziksel ve içerik özelliklerinin ödünç alma üzerinde etkili olup olmadı̆̆ çok fazla araştırılmamış bir konudur. Çalışmada bu konu Eskişehir Il Halk Kütüphanesi örneğinde incelenmiş ve diğer halk kütüphanelerinin de dikkate alacă̆ v ve yararlanacă̆ sonuçlar elde edilmiştir. Ayrıca, yayıncıların resimli çocuk kitapları tasarımında dikkate alacakları sonuçlar da elde edilmiştir. Geliştirdiğimiz "Resimli Çocuk Kitaplarını Değerlendirme Formu” da çalışmanın özgünlüğünü artırmıştır.

Anahtar Sözcükler: Çocuk edebiyatı; resimli çocuk kitaplarl; fiziksel ve içerik özellikleri; dış ve içyapı özellikleri; çocuğa görelik ilkesi; çocuk kütüphaneleri; Eskişehir Il Halk Kütüphanesi.

\footnotetext{
Abstract

The reading culture, which is generally created and strengthened through works of children's literature, has important functions in the mental (cognitive), spiritual, social, moral, linguistic and aesthetic development of children. If children encounter high quality books that are suitable for the principle of appropriateness for the child from their infancy period will put their reading culture on a solid and healthy foundation that will last throughout their lives. Public and children's libraries are social institutions that bring children together with various types of numerous children's books. However, they need to have a collection of children's books which are in high quality and which appeal to children in order to fulfill their significant role in promoting reading culture. Objective: This study aims to examine the illustrated preschool (early childhood) books in the collection of Eskişehir Provincial Public Library in terms of their physical (external) and content (internal) characteristics and the principle of relevance to
} 
Eskişehir İl Halk Kütüphanesi Dermesinde Bulunan Resimli Çocuk Kitaplarının Fiziksel ve İçerik Özelliklerinin Ödünç Alınma Üzerinde Etkisi

The Effect of Physical and Content Characteristics of Illustrated Children's Books in the Eskişehir Provincial Public Library's Collections on Borrowing

the child, and to reveal the impacts of this on borrowing. Method: Therefore, the scope of this study covers the illustrated printed books in Turkish for children aged 0-7 in the collection of Eskişehir Provincial Public Library which were published between 2015-2019. 130 books were used as a sample and population of the research is comprised of 2,197 books. In the research carried out with descriptive method, physical and content characteristics of sampled illustrated children's books and data related to the principle of relevance to the child were analyzed through "Illustrated Children's Books Evaluation Form" created by the researchers and evaluated by associating them with their borrowing status. Findings: According to the findings obtained in the study, 60,8\% of children's picture books in Eskişehir Provincial Public Library are borrowed 1-3 times a year on average; while 56,2\% of thick paperback books are borrowed 7 times or more per year on average, this rate is 5,3\% for thin paperback books; $81,9 \%$ of original children's books and 96,6\% of translated children's books were borrowed; while 96,6\% of children's picture books with visually appealing covers are borrowed, this rate drops to $81,7 \%$ for books whose covers are not visually appealing; 94,7\% of the books that are suitable for the child's interests and needs are borrowed, the rate of borrowing decreases to $66,7 \%$ for the books that are not suitable for the development of the child and to $81,2 \%$ for those that are partially suitable. It has been understood that 98,2\% of the children's picture books that will arouse the desire to read in the child, $89,5 \%$ of the partially in this quality and 72,3\% of the unqualified children's books are borrowed at least once a year. Implications: The results of the study shows that illustrated children books in the Eskişehir IHK collection are borrowed 1-3 times in average per year; the publication information in these books has not effect on the annual borrowing frequency but the characteristics of being original or translated affects the frequency of borrowing; there is no statistically significant correlation between the size of the books, availability of information relevant to the target age group on the books and the annual borrowing frequency; the attractiveness of the cover images, the fact that the cover images reflect the content (theme), the relevance of the pictures to the children to create a story, and the suitability of the picture and text ratio affect the borrowing. In the light of those findings, it has been concluded that the children's picture books in the collection of the Eskişehir Provincial Public Library which are suitable for the child's development level, interests and needs have a positive effect on the borrowing situation and they are borrowed more often when compared to others. With the findings and results presented in the study, the research has achieved its purpose. Originality: This research is important in terms of quality collection development and management processes in public and children's libraries, as it shows the physical and content elements that affect and do not affect borrowing in children's picture books. Whether the physical and content characteristics of children's books in a public library collection have an impact on borrowing is an under-researched subject. In the study, this subject was examined in the example of the Eskişehir Provincial Public Library and results that other public libraries would consider and benefit from were obtained. In addition, results that publishers will consider in the design of children's picture books were also obtained in the study. The "Illustrated Children's Books Evaluation Form" that we developed also increased the originality of the study. 
Keywords: Children's literature; illustrated children books; physical and content features; external and internal structure features; the principle of relevance to children; children's libraries; Eskişehir Provincial Public Library.

\section{Giriş}

Çocuk edebiyatı, çocuk için yapılan, çocuğa görelik ilkeleri ile çocuğun dil, duygu, düşünce dünyasına ve düzeyine uygun olan edebiyattır. Çocuk edebiyatı, çocuğun çeşitli gelişim alanlarındaki bilişsel, sosyal, ruhsal, dilsel, etik ve estetik gereksinimlerini karşılayarak, olumlu yönde etkilenmesinde ve okuma alışkanlığı kazanmasında çok önemli rol oynar (Sever, 2017, s. 19). Edebiyat kavramı çerçevesinde düşünüldüğünde bir çocuk edebiyatı eserinin taşıması gereken çeşitli özellikler olduğu söylenebilir. Bu özellikler, fiziksel özellikler-içerik özellikleri ya da dış yapı-içyapı özellikleri olarak adlandırılabilmektedir. Genel olarak çocuk kitaplarının fiziksel (dış yapı) özellikleri genel olarak kâğıt, kapak-cilt, harfler, boyut-biçim, resimler ve sayfa düzenidir. İçyapı özellikleri ise konu, tema, plan, kahramanlar (karakterler), dil ve anlatımdan oluşur (Gönen ve Aydos, 2016).

Çocuk edebiyatı eserlerinin nitelikli olmalarını belirleyen ilke çocuğa görelik ilkesidir. Bu ilke, Şirin (1994, s. 19) tarafindan "çocuklar için yapılacak edebiyatın çocuğun büyüme ve gelişme çağlarına, psikolojisine, sözcük ve kavram bilgisine, algılama düzeyine uygun” olması biçiminde tanımlanmaktadır. Bir başka deyişle çocuğa görelik ilkesi, bir çocuk kitabının çocuğun temel gelişim alanlarını ve evrelerini, ilgi, gereksinim ve duyarlılıklarını dikkate alması ve çocuğa uygun fiziksel ve içerik özelliklerine sahip olması demektir. Bu bağlamda, çocuğa göre kitap, çocuk gerçekliğine ve yazınsal (edebi) ilkelere uygun kitap anlamına gelmektedir.

Halk ve çocuk kütüphaneleri, çocuklara okuma kültürünü kazandırma ve geliştirmede önemli rollere sahip toplumsal kuruluşlardır. Söz konusu kütüphaneler bu işlevlerini sahip oldukları nitelikli dermeler aracılığıyla gerçekleştirebilirler. Bu nedenle, halk ve çocuk kütüphanelerinin çocuklara uygun nitelikli kitaplardan oluşan dermelere sahip olması büyük önem taşımaktadır. Kütüphanelerin genel hedefleri olabildiğince çok kullanılmaktır. Ödünç verme oranları kütüphaneler için en somut kullanım göstergeleri arasında sayılabilir. Nitelikli çocuk kitapları, dermelerin daha çok ödünç alınmasını sağlayacak, böylece kütüphanelerin kullanım düzeylerini de yükselterek, hedeflerini gerçekleştirmelerine katkıda bulunabilecektir.

$\mathrm{Bu}$ çalışmada, öncelikle çocuk edebiyatı ve çocuk kütüphaneleri konusunda yapılmış çalışmalarla ilgili literatür özetlenecek ve konunun temel kavramlarına açıklık getiren bir kuramsal çerçeve çizilecektir. Daha sonra Eskişehir İl Halk Kütüphanesi dermesinde bulunan ve örnekleme alınan 0-7 yaş grubu çocuklara yönelik resimli çocuk kitaplarına ilişkin fiziksel ve içerik özellikleri hakkında elde edilen bulgular verilerek değerlendirilecektir. Bu araştırmanın sonucunda okul öncesi (erken çocukluk) dönemi resimli çocuk kitaplarının nitelikleri ile ödünç alınma durumları arasında istatistiksel olarak anlamlı ilişkinin var olup olmadığı analiz edilecektir. 
Eskişehir İl Halk Kütüphanesi Dermesinde Bulunan Resimli Çocuk Kitaplarının Fiziksel ve İçerik Özelliklerinin Ödünç Alınma Üzerinde Etkisi

The Effect of Physical and Content Characteristics of Illustrated Children's Books in the Eskişehir Provincial

\section{İlgili Çalış̧malar}

Dünyada ve Türkiye'de resimli çocuk kitaplarının hem genel olarak çocuk kitabı ölçütlerine göre hem de halk kütüphaneleri dermeleri bağlamında değerlendirildiği çalışmalar bulunmaktadır.

Kocabaş (1999), 1997 yılında Türkiye'deki çocuk kütüphanelerinde bulunan çocuk kitaplarını fiziksel ve içerik özellikleri açısından değerlendirmiş ve genel olarak yetersiz oldukları sonucuna ulaşmıştır. Çalışmasının sonunda çocuk kütüphaneleri için kitap seçim işleminin konu uzmanları tarafından yapılmasını önermiştir.

Ankara'daki 20 çocuk kütüphanesinde en çok ödünç alınan 25 çocuk kitabının çocuk edebiyatı ilkeleriyle fiziksel ve içerik özellikleri açısından incelendiği bir başka çalışmada (Erkmen, 2017) söz konusu kitaplara ilişkin \%80’lerin üstünde olumlu sonuç elde edilmiştir. Araştırmada, 100 kütüphane kullanıcısı ile yapılan görüşmede çocukların ödünç alacakları kitap tercihini önemli ölçüde öğretmenlerin etkilediği anlaşılmıştır.

2000-2014 yılları arasında yayımlanmış resimli çocuk kitaplarını dış ve içyapı özellikleri çerçevesinde inceleyen Koçak (2017), kitapların resimleyen ve basım bilgisi içerme, kâğıt yapısı açısından ortalama, dil bilgisi ve evrensel değerlere uygunluk açılarından ise yüksek oranlarda olumlu niteliğe sahip olduğunu ortaya koymuştur.

Svab ve Zumer (2015), ebeveynlerin kütüphane kataloglarından çocukları için resimli çocuk kitaplarını hangi bibliyografik bilgilerle seçtiklerini belirlemeye yönelik olarak yaptıkları araştırmada, ebeveynlerin kitap seçimi konusunda zorluk yaşadıkları ve katalog bilgileri yerine kitapları bizzat görerek seçmeyi tercih ettikleri anlaşılmıştır. Ebeveynlerin kitap tercihlerinde özellikle kapak, resimler ve içeriğin etkili olduğu görülmüştür.

Gönen ve Aydos (2016), 3-6 yaş grubu resimli çocuk kitaplarını fiziksel ve içerik özellikleri açısından inceledikleri çalışmalarında, kitaplardaki konusal çeşitliliğin sınırlı olduğu sonucuna ulaşmışlardır.

Ankara'da bulunan halk kütüphanelerinin çocuk bölümlerinin dermelerinde yer alan resimli çocuk kitaplarının tematik yapılarına ilişskin olarak yapılan bir başka çalışmada (Yılmaz ve Gönen, 2018), söz konusu kitap temalarının çocukların mutluluk, dostluk, sevgi, yardımlaşma, arkadaşlık ve özür dileme gibi sosyal ve duygusal gelişim alanlarını güçlendirmesine katkıda bulunabilecek nitelikte olduğu anlaşılmıştır. Buna karşın, kitaplarda işlenen temaların, çocukların dilsel ve bilişsel gelişim alanlarına katkısının daha sınırlı olduğu görülmüştür.

Çolaklar'ın (2019) Bartın İl Halk Kütüphanesi dermesinde yer alan 2,995 okul öncesi ve ilk okuma kitaplarının fiziksel özelliklerini incelediği çalışmasında, kitapların sayfa düzeni, kâğıt niteliği, resimleme, taşınabilirlik, punto büyüklüğü açılarından çocuklara uygun olduğu saptanmıştır. Kitapların çok büyük bir bölümünün (\%87,3) otuz sayfadan az, kapak resimlerinin ilgi çekici ve renkli $(\% 85,1)$ ve okuma kolaylığı açısından da çocuklara göre olduğu $(\% 85,8)$ anlaşılmıştır.

Taşcı (2019) tarafından yapılan çalışma, 2019 yılında Ankara'daki kitapçı raflarında bulunan ve 0-3 yaş grubuna yönelik 135 resimli çocuk kitabının fiziksel özellikler açısından uygun, içerik özellikleri açısından ise yetersiz olduğu sonucuna ulaşmıştır. 
5-8 yaş grubuna hitap eden 149 resimli çocuk kitabının fiziksel ve içerik özellikleri açısından incelendiği bir başka çalışmada (Dönmezler, 2019), söz konusu kitapların fiziksel açıdan genel olarak uygun olduğu, resimleme ve içerik özellikleri açısından ise uygun olmadığı saptanmıştır.

Bir başka çalışmada (Wei ve Ma, 2020) ise resimli çocuk kitaplarının ebeveynler, çocuklar ve diğer kullanıcılar açısından çekicilik etkenleri saptanmaya çalışılmıştır. Araştırmada, katılımcıların resimli çocuk kitaplarını seçme yolları ve buna ilişkin okuma deneyimleri hakkında ilginç sonuçlar elde edilmiş ve kitapların görsel açıdan çekici olmalarının çocukların okuma isteğini önemli ölçüde artırdığı anlaşılmıştır.

$\mathrm{Bu}$ araştırmada diğer araştırmalardan farklı olarak okul öncesi (erken çocukluk) dönemi resimli çocuk kitaplarının fiziksel ve içerik özelliklerinin onların ödünç alınma sıklıklarını nasıl etkiledikleri incelenmiştir.

\section{Erken Çocukluk Dönemi, Çocuk Edebiyatı ve Çocuk Kütüphaneleri Erken Çocukluk Dönemi Gelişim Evreleri, Alanları ve Özellikleri}

Erken çocukluk dönemi gelişim evreleri, alanları ve özellikleri, kitaplara ait dış-içyapı özellikleri ile birlikte çocuk kitaplarının çocuğa görelik ilkesi bağlamında dikkate alınan temel iki boyuttan birisini oluşturur.

Erken çocukluk, Birleşmiş Milletler (2006, s. 3) tarafından "çocuğun sekiz yaşına kadar olan dönemi” olarak tanımlanmıştır. Erken çocukluk dönemi kendi içinde de sırasıyla 0-2 yaş arası bebeklik dönemi, 3-5 yaş arası okul öncesi dönemi, 6-8 yaş arası ise ilköğretimin ilk yılları olarak ayrılabilmektedir (Can, 2011, s. 18). Erken çocukluk dönemi, bireyin tüm yaşamını etkileyecek olan alışkanlıkları edindiği çok yönlü ve etkili bir evredir (Cüceloğlu, 1991, s. 331). Çocukların fiziksel ve bilişsel gelişim temellerinin çok büyük ölçüde çocukluk döneminde atıldığı söylenebilir.

Gelişim hızı ve özellikleri toplumdan topluma ve çocuktan çocuğa göre belirli ölçüde farklılık göstermekle birlikte, erken çocukluk gelişim süreci ve gelişim alanları evrensel nitelik taşır ve genellikle genetik ve çevresel etkenlerle ilişkilendirilir. Erken çocukluk dönemi gelişim süreci çoğunlukla fiziksel, bilişsel (zihinsel), sosyal, duygusal, dilsel ve ahlaki gelişim alanları çerçevesinde ele alınmaktadır.

Bebeklik ve erken çocukluk döneminde gözle görülen en belirgin gelişimin beden ve hareket gelişimini içeren fiziksel gelişim olduğu söylenebilir. "Vücuttaki hücre sayısının ve büyüklügünün artmasına bağlı olarak, vücut hacminin ve kütlesinin artması" (Cirhinlioğlu, 2010, s. 9) anlamına gelen fiziksel gelişimle birlikte sinir ve kas sistemi olgunlaşmakta ve çocuğun emeklemek, yürümek, yakalamak gibi ilk hareket gelişimleri başlamaktadır (Yenibaş, 2008, s. 34). Çocuğun bir kitabı elinde tutması ve sayfaları çevirmesi bu dönemin beklenen fiziksel gelişim özellikleri arasındadır. Adını yazabilmesi de bu özellikler arasında sayılabilir (Levine ve Munsch, 2019, s. 252).

Erken çocukluk dönemi için bir diğer gelişim süreci bilişsel (zihinsel) gelişim alanında görülmektedir. Bu alan, kişinin dünyaya geldikten sonra öğrenme ve dünyayı anlama çabası içine girdiği ve bunun sonucunda geliştirdiği zihinsel bir düzenle çevresine uyum sağladığ bireyleşme ve bilişsel gelişim sürecidir (Cüceloğlu, 1991, s. 346). Bilişsel gelişim, 
"kavramların, düşünme yeteneklerinin, belleğin, akıl yürütmenin ve başka çeşitli iç zihinsel işlevlerin gelişimi”' (Gander ve Gardiner, 1998, s. 193) olarak tanımlanır. Yüzeysel düşünmenin olduğu ve mantıksal düşünmenin gelişmediği bu dönemin çocuklara ilişkin gelişim etkinlikleri arasında sözcükleri kullanma, hayali ve öyküsel oyunlar aracıllğıyla yaşama hazırlanma, sürekli sorular sorma, öykü anlatmaktan ve dinlemekten hoşlanma, bildikleri şiir ve tekerlemeleri yineleme, kitaplarla daha çok ilgilenme söz konusudur (Bakırcıoğlu, 2011, s. 265; Cüceloğlu, 1991, s. 347; Dehart, Sroufe ve Cooper, 2004, ss. 380-383; Kandır, 2007, ss. 49-50).

Erken çocukluk döneminde dikkate alınan bir başka gelişim alanı, dil gelişimi ile ilgili olandır. Çocukların sesleri algılama ve sesler çıkarmasıyla başlayan bu dil gelişim süreci (Sever, 2018, s. 10), ağlama, babıldama, heceleme, tek sözcük söyleme ve sözcükleri birleştirme evreleri olarak adlandırılmakta ve değerlendirilmektedir (Oktay, 1994, ss. 167-170). Okul öncesi dönemde, çocuğun dil gelişimi hızlanır. Okul yılları ile birlikte ise okuma yazma, dilbilgisi kurallarını öğrenme ve sözcük dağarcığını geliştirme söz konusu olur (Santrock ve Yussen, 1992, s. 353). Sayılan tüm bu dilsel özelliklerin kazanılması ve geliştirilmesinde okuma ve kitaplar önemli işlev görür.

Sosyal, ruhsal ve ahlaki (etik) gelişim, erken çocukluk döneminde doğru değerlendirilmesi gereken çok önemli gelişim alanlarıdır. Gander ve Gardiner'e (1998, s. 274) göre, sosyal gelişim, çocukların belirli bir grubun üyeleri haline geldikleri, bu grubun değer, davranış ve inançlarını edindikleri süreçtir. Ruhsal gelişim, çocuğun sevgi, saygı, paylaşma, empati, dostluk, arkadaşlık vb. duygularının geliştiği duygusal gelişim alanıdır. Ahlaki gelişim de çocuğun, yaşadığı toplumun ürettiği doğru ya da yanlış kabul ettiği tutum ve davranışlara ilişkin sözlü normları/kuralları/ilkeleri öğrenme ve benimseme sürecidir. Çocukluk döneminde edinilen sosyal ve duygusal yetkinlik ve beceriler yetişkinlik dönemindeki davranışların da temelini oluşturmaktadır (Cüceloğlu, 1991, s. 356). Kitap ve okuma çocuklar için bu gelişim alanlarına katkıda bulunan önemli unsurlardır.

Bireyde yaşam boyu sürecek olan ve kısacası güzellik bilinci ve becerisi kazanmak biçiminde tanımlanabilecek estetik gelişim de erken çocukluk dönemi gelişim alanlarından birisi olarak düşünülebilir. Estetik gelişimde resimli ve estetik nitelikteki kitapların rolü önemlidir.

Burada kısaca açıklanmaya çalışılan çocuk gelişim evreleri, alanları ve özellikleri, bir kitabın çocuğa göre olup olmadığını belirlemede dikkate alınan ana unsurlardandır. Çünkü bu gelişim alanları, evreleri ve özellikleri, çocuk gerçekliği anlamına gelir ve çocuğun yaşamsal ilgi ve gereksinimlerini belirler. Bir çocuk kitabının, çocuğa göreliği bu ilgi ve gereksinimleri karşılayan nitelikte olmasına bağlıdır. 


\section{Çocuk Edebiyatının İşlevleri ve "Çocuğa Görelik"}

Birleşmiş Milletlerin Çocuk Haklarına Dair Sözleşme’sinde (1989, Madde 1), 0-18 yaş arasındaki bireyler çocuk olarak kabul edilir. Gelişim evrelerini henüz tamamlamadıkları için bu yaş grubundaki bireylerin fiziksel, bilişsel, sosyal ve duygusal açılardan çeşitli gereksinimleri bulunmaktadır. Genel olarak edebiyat, "olay, düşünce, duygu ve hayallerin dil aracılığıyla sözlü veya yazılı olarak biçimlendirilmesi sanatı, yazın” (TDK, 2019) biçiminde tanımlanmaktadır. Son derece hassas ve farklı gelişim özelliklerine sahip 0-18 yaş arası geniş bir grubu hedefleyen çocuk edebiyatı, dilsel ve estetik özenle değişik tür ve biçimlerde yazılan ve çeşitli işlevleri olan metinler anlamına gelir (O'Sullivan, 2010, s. 1). Çocuk edebiyatı, ana materyali dil olan ve çocuğun gelişim özelliklerini dikkate alan, çocuk dünyasına seslenen, anlama, kavrama, yorumlama yetilerini destekleyen, eğiten, eğlendiren yazılı veya sözlü yapıtlar olarak tanımlanır (Demirel, 2010, s. 45). Sever'e (2013a, s. 3) göre, çocuk edebiyatı ürünleri çocuğun gelişim evlerindeki gereksinimlerine uygun, hayal gücünü zenginleştiren, duygu ve düşüncelerine sanatsal anlam katan, görsel ve dilsel açıdan nitelikli eserlerdir. Şirin (1994, s. 9) çocuk edebiyatını, çocuksu edebiyat olarak niteler. Kısacası, çocuk edebiyatı, çocuklar için yapılan, çocuğa özgü ve çocuğa uygun edebiyattır. Bir başka deyişle çocuk edebiyatı, edebiyatın çocuklar için olan türüdür. Kuşkusuz çocuk edebiyatının okuru yalnızca çocuklar değil, her yaştan insan olabilir.

Çocuklar için edebiyat yaklaşımının 20. yüzyılda ortaya çıktığı söylenebilir. Bu edebiyatın doğuşunda çocuğun yetişkin dünyasından farklı eğilimlere, gelişim özelliklerine ve duyarlılıklara sahip olduğunun anlaşılması etkili olmuştur (Şirin, 1994, ss. 9-10). Dilidüzgün (2013, s. 46), bu olguyu, çocuk gerçekliği kavramı çerçevesinde, aynı nesnel olayı çocukların yetişkinlere göre farklı biçimde algılaması olarak açıklar. Çocuk edebiyatı, çocuğa özgü eğilimleri, gelişim özelliklerini ve duyarlılıkları çocuk gerçekliği bağlamında dikkate alan, bunları çocuğa hitap eden bir dil ve anlatımla edebiyat tadında yansıtmaya çalışan yazındır. Sever (2017, s. 17), çocuk edebiyatının, zengin içerikler sunma, çocuğun beğeni düzeyini yükseltme, gelişim aşamalarını destekleme, düş gücünü zenginleştirme ve kavrama düzeylerini güçlendirme boyutlarına dikkat çeker. Çocuk edebiyatının temel işlevi, çocuğun tüm gelişim alanlarındaki bilişsel, sosyal, ruhsal, dilsel, etik ve estetik gereksinimlerini karşılamaktır. Bu işlevler çocuğa okuma sevgisi ve alışkanlığı edindirmede çok önemli kazanımlar sağlar (Sever, 2017, s. 19). Çocuk, okumanın zevkini ve tadını en başta edebiyat ile almaya başlar. Çocuk edebiyatının genel işlevleri, çocuğa okuma sevgisi ve alışkanlığı edindirmek; onu bilgilendirmek; hayatı tanıtmak; dilsel, bilişsel ve görsel algı gelişimini desteklemek; düş gücünü geliştirmek; dinleme becerisini artırmak; sosyalleşmesine katkıda bulunmak; ruhsal gereksinimlerini karşılamak; okumaya ve yazmaya ilişkin istek yaratmak; yaşadığı kültürü tanımasına yardımcı olmak; estetik bilinç ve beceri kazandırmak ve keyif almasını sağlamak olarak sıralanmaktadır (Gönen ve Veziroğlu, 2013, ss. 10-11; Karatay, 2007, ss. 466-467).

Çocukların yetişkinlerden farklı eğilimlere, gelişim özelliklerine ve duyarlılıklara sahip olmaları anlamına gelen çocuk gerçekliği, çocuğa görelik ilkesinin de temelini oluşturmaktadır. Bir başka deyişle, çocuğa görelik, çocuğa özgü eğilimleri, gelişim özelliklerini, duyarlılıkları, ilgi ve gereksinimleri dikkate almak olarak ifade edilebilir. Şirin (1994, s. 19), çocuk edebiyatı bağlamındaki çocuğa görelik kavramında, çocuğun büyüme ve gelişme aşamalarına, psikolojisine, sözcük ve kavram bilgisine, algılama düzeyine uygun bir duyarlılığa dikkat çeker. 
Eskişehir İl Halk Kütüphanesi Dermesinde Bulunan Resimli Çocuk Kitaplarının Fiziksel ve İçerik Özelliklerinin Ödünç Alınma Üzerinde Etkisi

The Effect of Physical and Content Characteristics of Illustrated Children's Books in the Eskişehir Provincial

Kısacası, çocuk edebiyatı, çocuk için ve çocuğa göre yapılan, çocuğun dil, duygu ve düşünce dünyasına ve düzeyine uygun edebiyattır.

Çocuk edebiyatının çocuğa uygun/göre olmasında çocuğun bilişsel, ruhsal, sosyal, dilsel, etik ve estetik alanlardaki gelişim özelliklerinin yanı sıra bir çocuk edebiyatı eserinin taşıması/sahip olması gereken özellikler de dikkate alınır. Bu özellikler dış yapı ve içyapı özellikleri; tasarım/görsel metin özellikleri-içerik özellikleri ya da fiziksel (biçimsel) özellikleriçerik özellikleri (unsurları) gibi başlıklar altında toplanmaktadır.

Çocuk kitaplarının fiziksel (dış yapı) özellikleri (unsurları) arasında genel olarak boyut, biçim, kâğıt, kapak, cilt, harfler, sayfa yapısı ve resimler yer almaktadır.

- Çocuk kitapları genellikle küçük, orta, büyük ve kucak boy olarak dört boyutta, dikdörtgen, kare, üçgen, oval gibi farklı biçimlerde olabilmektedir. Farklı yaş grubundaki çocuklar, farklı boyut ve biçimdeki kitaplardan hoşlanabilmektedir.

- Resimli çocuk kitaplarında kâğıt kalitesi ve kalınlığı hitap ettiği yaş grubuna göre değişmektedir. Kalitesi nedeniyle kâğıdın kolayca yırtılması, bir sayfadaki yazıların ve resimlerin ön ya da arka sayfalardan görünmesi, 1şı̆̆ı çok yansıtan parlaklıkta olması gibi olumsuz özellikler çocuğun okuma isteğini ve çabasını olumsuz yönde etkileyebilir (Yılmaz, 2016, s. 71). Kâğıdın çocuğun göz sağlığına zarar vermeyecek nitelikte olması önemlidir.

- Sanatsal anlatımla tasarlanmış, kitap içeriğini yansıtan ve onu temsil edebilen bir kitap kapağı, çocuğun kitabı çekici bulması ve onu okumaya heveslendirmesi açısından önemli bir uyarandır (Sever, 1995). Kullanıcıları çocuklar olduğu için çocuk kitaplarında ciltlerin de sağlam olması gerekir.

- Kitabın boyutuna ve hedeflenen yaş grubuna göre değişiklik gösteren harf büyüklüğünde önemsenmesi gereken en önemli ölçüt çocukların el-göz eşgüdümünü sağlaması ve yazıların okunabilirliğidir (Seven, 2010, s. 106).

- Çocuk kitaplarında önemli fiziksel özelliklerden birisi de sayfa düzenlemesidir. Sayfa düzeninin okuma ve izleme rahatlığı sağlaması, estetik dengeye sahip olması bunun için sayfalardaki resim, metin, kenar boşlukları ve diğer unsurların oransal açıdan birbiriyle uyumlu olmas1 gerekmektedir (Sever, 2013b, s. 59).

- Çocuk edebiyatı, işlev ve amaçlarını resimlerle gerçekleştirebilir. Çocuğun düşünme ve düş dünyasını geliştiren resimler kitaplarda kavram ve düşüncelerin aktarılmasını sağlar (Göknil, 1994, s. 140). Resimli çocuk kitaplarındaki resimlerin estetik ve çocuğun düzeyine ve gelişim evresine uygun olması çok önemlidir. Kitapta geçen olaylar çocuğa resimlerle de anlatıldığ 1 için resim ve metin dengesi çok iyi kurulmalıdır. Öykü resimlerle uyumlu olmalıdır (Demirel, 2010, s. 68). Ayrıca resimlerin metin olmadan da hikâyeyi anlatma gücüne sahip olması gerektiği bilinir.

Çocuk kitaplarının içerik (içyapı) özellikleri (unsurları) tema, konu, kahramanlar (karakterler), plan, dil ve anlatımdan oluşur. Sever'e (2013b, s. 63) göre içerik, yazar ve çizerin, sözcüklerle resmin anlatım gücünün birlikte kullanılarak çocuklara aktarmaya çalıştığı duygu ve düşünceler bütünüdür. 
- Tema, bir edebiyat yapıtında üzerinde durulan düşünce, görüş veya yönelimlerdir (Oğuzkan, 1983'ten aktaran Uludağ, 2010, s. 83). Sever'e (2013b, s. 63) göre tema, eserde ele alınan konu ile çocukta yaratılmak istenen etkidir.

- Çocuk edebiyatı yapıtlarında çocuğa göre konu, çocuklar için anlama güçlüğü yaratmayan, çocuğun tanıdığı hayata uygun ve çocukları düşünmeye yönlendiren nitelikte olması anlamına gelmektedir. Bunlar aynı zamanda çocuk için konunun ilgi çekici olmasını sağlayan konusal özelliklerdir. Konular içinde bulunulan toplumun kültürel değerleri ile evrensel etik değerleri yansıtmalıdır (Erbay ve Aydoğan, 2006, s. 226). Ayrıca kitaplarda işlenen konuların gerçekçi olması ve çocuğun toplumsallaşmasına katkı sağlaması gerekir. Çocuğun barış, dostluk ve sevgi gibi güzel anlayışları kazanmasını sağlayan konular tercih edilmelidir (Sever, 2017, s. 121). Çocuk edebiyatı yapıtlarında siyasal, dinsel, ırkçı vb. düşünceler yer almamalıdır.

- Çocuk kitaplarında yer alan "kahramanlar (karakterler)" önemli işlevlere sahip içerik unsurlarındandır. Çocukların okudukları kahramanlara özendiği ve onları taklit ettikleri söylenebilir. Çocuklar kahramanların davranış, tutum, fiziksel ve ruhsal özelliklerinden etkilenir, onlara inanır ve güvenirler. Çocuk, okuduğu eserde özdeşim kurduğu bir kahramanı arkadaş olarak görür, ondan hayatta karşılaşabileceği çeşitli sorunlarda nasıl davranması gerektiğini öğrenir (Sever, 2013b, s. 64; Yılmaz, 2016, s. 85). Ancak kahramanlar çocukları yaşam gerçekliğinden koparacak nitelikte de olmamalıdır. Her şeyi bilen, hatasız, ideal örnek kahramanlar çocuk gerçekliğine aykırı oldukları için çocuğun özdeşim kurmasını engelleyecektir. Dolayısıyla kahramanlar iyi-kötü, doğruyanlış, güzel-çirkin arasında dolaşan ve çelişkiler yaşayan tipler olmalıdır (Karataş, 2014, s. 66).

- Çocuğun bilişsel ve dil gelişim düzeyine uygun anlatım biçimi çocuğa göre edebiyat yapıtları için önemli bir başka ölçüt anlamına gelir. Çocuk kendisine alışık olduğu bir anlatım biçimi ile seslenilmesini ister (Karatay, 2007, s. 465). Süslü, dolambaçlı, abartılı ve uzun anlatımlardan uzak durulmalı, çocuğun rahatlıkla anlayabileceği sade, akıcı ve anlaşılır anlatım biçimleri yeğlenmelidir. Ayrıca kitaplardaki cümle yapıları çocukların kelime dağarcıkları ile gelişim evreleri dikkate alınarak oluşturulmalıdır (Çakmak Güleç ve Geçgel, 2006, s. 185).

- Konunun, kahramanların ve temanın bir yapıta uyum içinde yerleştirilmesi, plan olarak tanımlanmaktadır. Çocuk kitaplarında tutarlı olması gereken planlar tema ve konu arasında uyum sağlamalıdır. Gereksiz ayrıntılardan uzak tutulan öyküde geçen olaylar, çocuğun heyecan ve ilgisini canlı tutacak kısa, açık, anlaşılır ve tutarlı biçimde bir sıra izlemeli ve ilerlemelidir (Demircan, 2006, s. 15; Seven, 2010, s. 108).

Kısacası, çocuğa görelik ilkesinin temel unsurları arasında daha önce açıklanan çocuğun gelişim özellikleri yanı sıra burada özetlenen çocuk kitaplarına ilişsin fiziksel ve içerik özellikleri de yer almaktadır.

Kuramsal çerçeveye dayanarak kapsamlı ve genel bir tanım yapmak gerekirse, çocuğa görelik ilkesi, bir çocuk kitabının çocuğun fiziksel, bilişsel, sosyal, ruhsal, dilsel, etik ve estetik gelişim evrelerini, düzeyini, özelliklerini, ilgi, gereksinim ve duyarlılıklarını dikkate alması ve çocuğa uygun fiziksel ve içerik özelliklerine sahip olması demektir. Bu tanım bağlamında, çocuğa göre kitap, fiziksel ve içerik özellikleri açısından çocuk gerçekliğine (çocuğun temel 
Eskişehir İl Halk Kütüphanesi Dermesinde Bulunan Resimli Çocuk Kitaplarının Fiziksel ve İçerik Özelliklerinin Ödünç Alınma Üzerinde Etkisi

The Effect of Physical and Content Characteristics of Illustrated Children's Books in the Eskişehir Provincial

özellikleri, ilgi, gereksinim ve duyarlılıkları ile duygu, düşünce ve kavram dünyasını) uygun nitelikli edebiyat eseridir. Bir başka ifadeyle, çocuk gerçekliğine ve yazınsal (edebi) ilkelere uygun kitap, çocuğa göre kitaptır.

\section{Resimli Çocuk Kitapları}

$\mathrm{Bu}$ çalışma kapsamında yer alan resimli çocuk kitapları konusu ile ilgili kısa bir kavramsal çerçeve çizmek yararlı olacaktır. Çocuk edebiyatının bir türü sayılan resimli çocuk kitapları masallar, şiirler, bilmeceler gibi türlerden daha farklıdır. Resim-metin uyumu ile tanımlanan resimli çocuk kitapları bu nedenle özel bir tür olarak da kabul edilir (Tunnel ve Jacobs, 2008, s. 61). Resimli çocuk kitaplarının çocuk edebiyatı türü olarak kabul edilmesiyle ilgili farklı yaklaşımlar bulunmaktadır. Bilgi veren ancak yazınsal nitelikte olmayan ABC kitapları, kavram kitapları gibi türler bulunmakla birlikte, resimli çocuk kitaplarının çoğunluğunu öykü kitapları oluşturur. Çocuğun, edebiyatla ilk karşılaştı̆ı kitaplar resimli öykü kitaplarıdır. Yazınsal ilkeler çerçevesinde oluşturulmuş resimli öykü kitapları, çocuk edebiyatı yapıtları arasında kabul edilmektedir (Alpöge, 2005, s. 17).

Resimli çocuk kitapları "0-7 yaş çocuklara yönelik, içinde öykü benzeri anlatılara yer verilen ürünler" (Dilidüzgün, 2013, s. 109) olarak tanımlamaktadır. Tuncer (1994, s. 202) de, İngilizcede "picture book", Almancada "bilderbuch" ve Fransizcada "albüm" olarak adlandırılan resimli çocuk kitaplarını, yedi yaş ve öncesi çocuklara okunan veya bu yaş grubu çocukların okudukları kitaplar biçiminde ele almaktadır. Ancak her türden resimli kitap bu türe girmemektedir. Resimli çocuk kitaplarında temel olan nokta, öykünün çocuğa hem metin hem resim yoluyla anlatılması, bu iki unsurun birbirini bütünlemesi ve resmin daha güçlü bir unsur olarak tek başına dahi anlatım gücüne sahip olmasıdır. Resimli çocuk kitapları "çocuğu çizginin, rengin ve sözcüklerin anlatım olanaklarıyla buluşturan, onlara yaşamı ve insanı sanatsal kurgular içinde tanıtan araçlardır” (Sever, 2013a, s. 3). Çocuk özellikle erken çocukluk döneminde önce resimli kitaplar, sonra resim ağırlıklı resim-metin uyumlu kitaplarla ve son olarak da metin ağırlıklı resim-metin uyumlu kitaplarla buluşmalıdır (Şirin, 2007, s. 53).

Resimli çocuk kitapları, öğretici ve edebi nitelikli resimli çocuk kitapları olarak gruplandırılabilmektedir (Bassa, 2013, ss. 180-181). Öğretici nitelikteki resimli çocuk kitapları, öykünün sadece resimlerle anlatıldığı ya da çok az metin bulunan kitaplardır (Şahin, 2014). Edebi nitelikli resimli öykü kitaplarında ise öykü, resim ve metnin uyumlu dengesiyle ilerler ve sadece sözcüklerle aktarılır. Edebi nitelikli resimli çocuk kitapları öğretici olma kaygısı olmadan çocuğu doyuma ulaştıran eserlerdir. Edebi nitelikli resimli öykü kitaplarında amaç, çocukların duygu ve düşünce dünyalarını dilsel ve görsel unsurlarla zenginleştirilmesi, çocuğa yaşamın ve insanın tanıtılmasıdır (Sever, 2017, s. 30).

Resimli çocuk kitapları ile ilgili olarak yapılan bu çalı̧̧ma kapsamında belirtilmesi gereken önemli nokta, hem öğretici hem de yazınsal nitelikli çocuk kitaplarının çocuğa göre olması gerektiğidir. 


\section{Çocuk Kütüphaneleri ve Derme}

Çocuk kütüphanesi Halk Kütüphaneleri Yönetmeliği’nde (2012), “il veya ilçe halk kütüphanesine bağlı olarak on dört yaşına kadar olan çocuklara ayrı bir binada hizmet veren kütüphane" biçiminde tanımlanmıştır. Türkiye'de halk kütüphanelerinin içinde yer alan çocuk bölümleri de çocuk kütüphanesi olarak kabul edilebilir. IFLA'ya (2018, s. 4) göre ise çocuk kütüphaneleri, "1rk, din, cinsiyet, kültürel geçmiş, sosyo-ekonomik durum, zihinsel ya da fiziksel becerileri ne olursa olsun bebeklik, çocukluk ve genç yetişkinlik dönemlerindeki çocukları içeren, 'herkes için hizmet' ilkesiyle hareket eden kurumlar'dır. Çocukların farklı deneyimlerle, sosyalleşebileceği ve keyifli zamanlar geçirecekleri ortamlar olarak çocuk kütüphaneleri çocuk ile kitap arasındaki bağları da güçlendirir (IFLA, 2007, s. 4).

IFLA (2003) tarafından çocuk kütüphanelerinin amaçları arasında sıralanan ve okuma olgusu ile doğrudan ya da dolaylı biçimde ilgili görünen ilk iki madde şöyledir:

- Her çocuğun hakkı olan bilgi, işlevsel, görsel, dijital ve medya okuryazarlığı, kültürel gelişim, okuma gelişimi, yaşam boyu öğrenme, boş zamanlar için yaratıcı programlara erişimi kolaylaştırmak,

- Çocukların açık erişimli tüm kaynaklara ve ortamlara erişimini sağlamak”tır.

Çocuk kütüphanesi amaçları arasında yer alan okuma gelişimini kolaylaştırmanın nitelikli çocuk kitapları ile olacağı kabul edilmesi gereken bir gerçektir. Aydın (2019) çalışmasında, çocuk kütüphanelerinde nitelikli derme oluşturmanın önemine dikkat çekerek, konunun kuramsal içeriğinde hem çocuk kitaplarının hem de çocuk kütüphanelerinin sahip olmaları gereken özellikleri belirtir. Polat (2018, s. 445), dermenin bir kütüphane için önemli nitelik ölçütleri arasında yer aldığını vurgular. Çocuk kütüphaneleri bu nedenle nitelikli ve yeterli sayıda çocuk kitapları dermelerine sahip olmalı, çocukların gereksinimine yanıt verecek nitelikte ve çeşitlilikte kaynağı içermelidir. Çocuk kütüphaneleri hem basılı hem de çevrim içi kaynaklardan oluşan güçlü dermeleri aracılığıyla her türden düşünce ve değeri yansıtmalıdır. Kütüphane için kaynakların seçiminde kullanıcı istek ve önerileri de dikkate alınmalıdır. Dermeler çekici, güncel ve iyi bir biçimde düzenlenmiş olmalıdır (IFLA, 2018, s. 13). Tüm çocuklar için eşit hizmet olanakları yaratan çocuk kütüphaneleri, çocuklara nitelikli, zengin, estetik ilkelerle oluşturulmuş, edebiyat ve sanat değeri taşıyan, hem çocuğun hem de yetişkinlerin keyifle kullanabilecekleri derme sunma sorumluluğuna sahiptirler (Y1lmaz, 2019, s. 35).

Çocuklara yönelik derme geliştirme uzmanlık ve zaman isteyen bir işlemdir (Sullivan, 2005, s. 35). Büyük bir dikkat ve duyarlılıkla oluşturulan çocuk kütüphanesi dermeleri yetişkin kütüphane dermelerine göre farklıdır. IFLA'ya (2003) göre, kütüphanelerde çocuklar için derme oluşturulurken temel ölçütler olarak kaynakların; nitelikli ve yaş grubuna uygun olmasına, güncel ve doğru bilgiler içermesine, farklı değerleri, fikirleri ve yerel topluluk kültürünü yansıtmasına ve aynı zamanda küresel toplumla bütünleşmeyi sağlayacak yayın ve hizmetleri içermesine dikkat edilmelidir.

Görüldüğü gibi, çocuk kütüphaneleri için derme oluşturma ve geliştirme, çocuğa görelik ilkesi çerçevesinde ve son derece titizlikle gerçekleştirilmesi gereken işlemler sürecidir. Çünkü çocuk kütüphaneleri, çocukların zihinsel (bilişsel), ruhsal, sosyal, dilsel, etik (ahlaki) ve estetik gelişimlerini destekleme işlevlerini çocuklara nitelikli okuma materyalleri ile kazandırdıkları okuma kültürü aracılığıyla yerine getirirler. Bu nedenle çocuk kütüphanesi dermelerinin çocuğa 
Eskişehir İl Halk Kütüphanesi Dermesinde Bulunan Resimli Çocuk Kitaplarının Fiziksel ve İçerik Özelliklerinin Ödünç Alınma Üzerinde Etkisi

The Effect of Physical and Content Characteristics of Illustrated Children's Books in the Eskişehir Provincial

görelik ilkeleri çerçevesinde uygun fiziksel ve içerik özellikleri taşıyan resimli çocuk kitaplarını sunması büyük önem taşır. Çocuk kütüphanelerinin nitelikli dermelere sahip olmaları bu dermelerin kullanım düzeylerini de artıracaktır.

Türkiye'de halk ve çocuk kütüphaneleri için yayın seçme süreci Kültür ve Turizm Bakanlığı Yayın Seçme Yönetmeliği (2005) çerçevesinde gerçekleşmektedir. İlgili yönetmelikte söz konusu kütüphanelere yayın seçiminden sorumlu komisyon ve kurullar ile hangi işlemlerin yapılması gerektiği açıklanmaktadır. Yönetmeliğe göre, halk kütüphanelerine sağlanacak yayınları, Kültür ve Turizm Bakanlığı bünyesindeki Yayın Seçme Kurulu ve iller düzeyinde de Yayın İnceleme Komisyonları seçmektedir. Yönetmelik çerçevesinde, Yayın İnceleme Komisyonu kütüphanesi için uygun gördüğü ve istediği yayınların seçimini yapar ve sağlanması için Yayın Seçme Kuruluna önerir. Türkiye'de halk ve çocuk kütüphanelerine yönelik yayın seçim ve sağlama işlemleri büyük ölçüde ilgili bakanlık bünyesinde oluşturulan Yayın Seçme Kurulu tarafından yapılmaktadır (Cengiz, 2017, s. 47). Kütüphaneler ve Yayımlar Genel Müdürlüğ̈nün (KYGM) istatistiki verilerine göre 2019 yllında halk ve çocuk kütüphanelerine merkezden (KYGM tarafindan) 1,094,950 adet, kütüphaneler tarafindan ise 61,926 adet kitap satın alınmışır. Buna göre, 2019 yılında Türkiye'deki halk kütüphanesi dermelerine eklenen kitapların sadece $\% 5,35$ 'i kütüphanelerin kendileri tarafından seçilmiş ya da seçtikleri bakanlık tarafindan alınmıştır (Kütüphaneler ve Yayımlar, 2019). Çocuk kütüphaneleri için derme oluşturma süreçleri açısından dikkat çekilecek bir konu da, Türkiye'de halk ve çocuk kütüphanelerine çocuk kitapları seçimi için ayrı bir yönetmeliğin bulunmaması ve bu işlemin de Kültür ve Turizm Bakanlığı Yayın Seçme Yönetmeliği'nde (2005) yer alan ve tüm kitaplar için geçerli olan genel ölçütlere göre yapılmasıdır.

\section{Eskişehir İl Halk Kütüphanesi}

Eskişehir'de 1874 yllında Kurşunlu Camii bünyesinde kurulmuş olan ilk kütüphane İstiklal Savaşı'nda yıkıldığında 01.06.1926 tarihinde Muhasebe-i Hususiye'ye ait binada Memleket Kütüphanesi adıyla yeniden hizmete başlamıştır. Kütüphane, 1950-1968 yılları arasında Kültür ve Turizm Bakanlığına bağlı yeni hizmet binasında hizmet vermiştir. Eskişehir İl Halk Kütüphanesi, 05.07.1968 tarihinde 2 katlı 861 metrekare kullanım alanına sahip hizmet binasına taşınmıştır (Eskişehir İl Halk Kütüphanesi, 2014). Bu binanın da yetersiz kalması üzerine 2016 yılında yıkılmış ve yerine yapılan yeni binanın inşaat işleri halen devam etmektedir. Eskişehir İl Halk Kütüphanesi, 2016 yılından bu yana geçici olarak Hacı Süleyman Çakır Kız Anadolu Lisesinde hizmet sunmaktadır.

Eskişehir İl Halk Kütüphanesinde toplam 21 personel bulunmaktadır ve bunların 8'i kütüphanecidir. Kütüphanede danışma ve ödünç verme hizmetleri, çocuklara yönelik hizmetler, gezici kütüphane hizmeti, konuşan kitaplık, internet hizmeti, eğitici ve kültürel etkinlikler ile geçici koleksiyon hizmetleri yürütülmektedir.

Eskişehir İl Halk Kütüphanesinin dermesindeki toplam kitap sayısı 2020 yılı itibariyle 121,744'tür. Bu kitapların 19,447'si çocuklara, 1,630'u gençlere, 39,817'si yetişkinlere ve 60,850 'si de genel kullanıcılara yöneliktir. Kütüphaneye 2020 yılı içerisinde 6,851 yeni kitap 
gelmiştir. Bu kitapların \%72'si (4,981) KYGM tarafından, \%9'u (569) ise kütüphane tarafından satın alınmıştır. Diğer kitaplar (\%19) bağış yoluyla sağlanmıştır.

2020 yılında kütüphaneden ödünç verilen toplam kitap sayıs1 78,492'dir. Ödünç verilen kitapların 1,351'i okul öncesi çocuk kitapları, 18,172'si ise genel çocuk kitaplarıdır. Eskişehir İl Halk Kütüphanesinde 2020 yılında ödünç verilen kitapların \%25'i çocuk kitaplarıdır. Kütüphanenin toplam üye sayısı 68,745'tir. Bu üyelerin 113'ü okul öncesi, 13,333'ü çocuk, 37,765'i yetişkin, 16,947 'si genç ve 587 'si de 65 yaş üstüdür. ${ }^{1}$

\section{Araştırmanın Amacı, Kapsamı ve Yöntemi}

Çalışma, çocuk kütüphanelerinin nitelikli çocuk dermelerine sahip olmasının onların işlevlerini yerine getirebilmeleri açısından zorunlu olduğu gerekçesi ve yaklaşımı çerçevesinde ele alınmıştır. Araştırmanın amacı, Eskişehir İl Halk Kütüphanesi dermesinde bulunan resimli çocuk kitaplarını fiziksel ve içerik özellikleri ile çocuğa görelik ilkeleri çerçevesinde değerlendirmek ve bu özelliklerin kullanıcıların ödünç alma eğilimleri üzerinde etkili olup olmadığını ortaya koymaktır. Bu amaç bağlamında, araştırmanın problemi; "Eskişehir İl Halk Kütüphanesi dermesinde bulunan resimli çocuk kitapları fiziksel ve içerik özellikleri ile çocuğa görelik ilkeleri açısından nasıldır ve bu özellikler kitapların ödünç alınma durumlarında etkili midir?" biçiminde belirlenmiştir. Çalışmada aşağıdaki araştırma soruları yanıtlanmaya çalışılmıştır:

1. Eskişehir İl Halk Kütüphanesi dermesinde bulunan resimli çocuk kitapları fiziksel ve içerik özellikleri açısından nasıldır?

2. Eskişehir İl Halk Kütüphanesi dermesinde bulunan resimli çocuk kitapları, çocukların gelişim özelliklerine ve düzeylerine uygun mudur?

3. Eskişehir İl Halk Kütüphanesi dermesinde bulunan resimli çocuk kitaplarının fiziksel ve içerik özellikleri ile çocuğa görelik durumları, onların ödünç alınma eğilimlerinde etkili midir?

Araştırmanın hipotezi de şöyle oluşturulmuştur: Eskişehir İl Halk Kütüphanesi dermesinde yer alan resimli çocuk kitaplarının fiziksel ve içerik özellikleri onların ödünç alınma durumlarında etkili olmaktadır.

Araştırma kapsamına, Eskişehir İl Halk Kütüphanesi dermesinde bulunan ve 2015-2019 y1lları arası yayımlanmış 0-7 yaş arası gruba yönelik Türkçe dilinde basılı resimli çocuk kitapları dâhil edilmiştir. Kütüphane dermesindeki resimli çocuk kitaplarının toplam sayısını belirlemek için KOHA otomasyon sisteminde yer alan 372.412 Dewey Onlu Sinıflama Sistemi numarası dikkate alınmıştır. 372.412 sınıflama numarası "okuma kitapları, okul öncesi ve okul öncesi kitapları” (Dewey, 1993, s. 628) için kullanılmaktadır. Bu bağlamda, 15 Ekim 2020 tarihi itibariyle Eskişehir İl Halk Kütüphanesi KOHA katalog tarama modülünden 372.412 sınıflama numarası verilen ve son beş yılda (2015-2019) yayımlanmış çocuk kitapları belirlenmiştir. Araştırma evreni bu kitaplardan oluşmuştur. Araştırma örneklemi de belirlenen evren kapsamında rastgele örnekleme tekniği ile saptanmıştır. Araştırma evrenine ve örneklemine ilişkin veriler Tablo 1'de sunulmaktadır.

\footnotetext{
${ }^{1}$ 01.01.2021 tarihinde Eskişehir İl Halk Kütüphanesinden görüşme yoluyla elde edilen verilerdir.
} 
Eskişehir İl Halk Kütüphanesi Dermesinde Bulunan Resimli Çocuk Kitaplarının Fiziksel ve İçerik Özelliklerinin Ödünç Alınma Üzerinde Etkisi

The Effect of Physical and Content Characteristics of Illustrated Children's Books in the Eskişehir Provincial Public Library's Collections on Borrowing

\section{Tablo 1}

Araştırma Evreni ve Örneklemi

\begin{tabular}{lcccc}
\hline & \multicolumn{2}{c}{ Evren } & \multicolumn{2}{c}{ Örneklem } \\
\cline { 2 - 6 } Yayın y1l & $\mathrm{N}$ & $\%$ & 25 & $\%$ \\
\hline 2015 & 422 & 19,2 & 30 & 22,8 \\
2016 & 501 & 22,8 & 36 & 27,9 \\
2017 & 613 & 27,9 & 26 & 19,7 \\
2018 & 433 & 19,7 & 13 & 10,4 \\
2019 & 228 & 10,4 & 130 & 100,0 \\
\hline Toplam & 2197 & 100,0 & & \\
\hline
\end{tabular}

Araştırmada evrenini oluşturan toplam 2,197 kitaptan 130'u örnekleme alınmıştır. 0,99 güven düzeyi ve 0,05 hoşgörü düzeyine göre 3,000'e kadar olan kitle genişliğini (evreni) 121 birim temsil edebilmektedir (Çıngı, 1990, s. 261). Bu durumda, 130 olan araştırma örneklemi istatistiksel olarak evreni temsil etmektedir.

Araştırma betimleme yöntemi ile gerçekleştirilmiştir. Betimleme yöntemi, araştırılan nesnenin ya da olgunun var olan durumunu nitelemeye ve açıklamaya çalışan bir yöntemdir. Bu yöntem ile amaç, bir kurum, birey, grup, durum ya da olgunun düzgün bir portresini ortaya çıkarmaktır (Altunışık, Çoşkun, Bayraktaroğlu ve Yıldırım, 2010, s. 69; Kaptan, 1998, s. 59).

Çalışmada, Eskişehir İl Halk (EİH) Kütüphanesi dermesinden araştırma kapsamına alınan resimli çocuk kitaplarının fiziksel ve içerik özellikleri ile çocuğa görelik durumları açısından değerlendirilebilmesi için "Resimli Çocuk Kitaplarını Değerlendirme Formu” hazırlanmıştır. ${ }^{2}$ Ayrıca çalışma kapsamında, EİH Kütüphanesi dermesinde yer alan resimli çocuk kitaplarının fiziksel ve içerik özelliklerine dair yerinde gözlem ve incelemeler yapılmıştır. Araştırma verileri, geliştirilen bu form aracılığıyla toplanmıştır. Sözü edilen "Resimli Çocuk Kitaplarını Değerlendirme Formu"nun ilk hali Eylül 2020'de çocuk edebiyatı yazarı, akademisyen ve kütüphanecilerden oluşan konu uzmanlarının ${ }^{3}$ görüşlerine sunulmuştur. Söz konusu uzmanlardan alınan geri bildirimler çerçevesinde gözden geçirilen form ile 15 kitap üzerinden bir ön-test uygulaması gerçekleştirilmiş ve forma son hali verilmiştir.

Elde edilecek verilerin güvenirliğinin saptanması için değerlendirilen kitaplara ait aynı veri seti dört konu uzman ${ }^{4}$ tarafından Resimli Çocuk Kitaplarını Değerlendirme Formuna göre ayrı ayrı kodlanmıştır. Daha sonra bu kodlamalar, aralarındaki benzerlik oranını belirlemek için karşılaştırılarak değerlendirilmiştir. Veri setine örneklemden rastgele beş resimli çocuk kitabı dâhil edilmiştir. Araştırmanın kodlama güvenilirliğini saptamak için farklı uzmanlar tarafından kodlanan veri setinin kodlama benzerliğinin minimum $\% 80$ olması beklenir ve bu benzerlik şöyle hesaplanır:

\footnotetext{
${ }^{2}$ Bkz. EK 1.

${ }^{3}$ Çocuk edebiyatı yazarları Sevim Ak, Nur İçözü, Hacettepe Üniversitesi Anaokulu psikoloğu ve çocuk edebiyatı yazarı Nihan Temiz, Anadolu Üniversitesi Çocuk Gelişimi ve Eğitimi Bölümü Araştırma Görevlisi Gülhan Yılmaz Bursa, Ankara Ali Dayı Çocuk Kütüphanesi kütüphanecisi Günay Uysal, İzmir Bornova Çocuk Kütüphanesi kütüphanecisi Asuman Nesibe Gök ve Aydın İl Halk Kütüphanesi kütüphanecisi Nuran Akman.

${ }^{4}$ Sevim Ak, Nihan Temiz, Nuran Akman ve Gülhan Yılmaz Bursa.
} 
Güvenirlik = görüş birliği sağlanan kodlama / (görüş birliği + görüş ayrılı̆̆ $) * 100$ (Miles ve Huberman, 1994, s. 64).

Kullanılan güvenilirlik modeli çerçevesinde çalışmadaki kodlayıcı uzmanlar arasındaki uyuşma oranı \%83,9 olarak saptanmıştır. Böylece aynı veri setini kullanan dört farklı kodlayıcının ilgili forma göre oluşturduğu yanıtların beklenen istatistiksel oranda uyuştuğu anlaşılmıştır.

Resimli Çocuk Kitaplarını Değerlendirme Formunda 3 bölüm ve 63 soru yer almaktadır. İlk bölüm 22 sorudan oluşmaktadır. Bu bölümde kitap adı, yazar, yayıncı, basım bilgisi, sayfa yapısı, özgün ya da çeviri olma durumu, resimleyen, çeviren, konu numarası, dermeye katıldığ1 y1l, hitap ettiği yaş kaydı, boyut, biçim, cilt ve kapak türü, kitabın fiziksel hali ve ödünç alınma sıklığı ile ilgili özellikler ile kitaba ait bibliyografik bilgiler bulunmaktadır. İkinci bölümde ise kitapların fiziksel özelliklerini (boyut ve biçim, kâğıt cinsi, kapak ve cilt türü, harfler, sayfa yapısı ve resimleme durumlarını) saptamaya ilişkin 18 soru yer almıştır. Üçüncü bölüm ise, kitapların içerik özelliklerini (tema, kahramanlar, konu, dil-anlatım ve plan) ve çocuklara görelik durumunu saptamaya ilişkin birisi açık uçlu olmak üzere toplam 23 soruyu kapsamaktadır.

Örnekleme alınan 130 resimli çocuk kitabına ilişkin ödünç alınma verileri, Türkiye'deki halk kütüphanelerinin ortak biçimde kullandığı Kültür ve Turizm Bakanlığı Kütüphaneler ve Yayımlar Genel Müdürlüğü KOHA otomasyon sisteminde açılan kişisel hesapla 15 Ekim 2020 tarihinde elde edilmiştir. Söz konusu tarihten sonraki ödünç alınma verileri çalışmaya dâhil edilmemiştir. KOHA kütüphane otomasyon sisteminde seçilen bir halk kütüphanesinde her kitabın dermeye girdiği tarihten itibaren toplam ödünç alınma sayılarına ulaşılabilmektedir. Örnekleme alınan resimli çocuk kitaplarına ilişkin elde edilen bu sayılarla yıllık ortalama ödünç alınma sıklıkları hesaplanmış ve araştırmada bu hesaplama ile elde edilen veriler değerlendirilmiştir.

Resimli Çocuk Kitaplarını Değerlendirme Formu ile elde edilen araştırma verileri SPSS 22.0 (Statistical Package of Social Science) istatistik programı ile analiz edilmiştir. Resimli çocuk kitaplarının ödünç alınma sıklıkları ile fiziksel ve içerik özellikleri (bağımlı-bağımsız değişkenler) arasındaki ilişkiyi (kitapların fiziksel ve içerik özelliklerinin ödünç alınma üzerinde etkisini) istatistiksel olarak ortaya çıkarmak için ki-kare analizi uygulanmıştır.

\section{Bulgular ve Değerlendirme}

Çalışmanın bu bölümünde, Eskişehir İl Halk Kütüphanesi (Eskişehir İHK) dermesinde yer alan ve örnekleme alınan resimli çocuk kitaplarının fiziksel ve içerik özellikleri kısaca verilerek bu özelliklerin ödünç alınmaya etkileri ortaya konulacaktır.

Resimli Çocuk Kitaplarını Değerlendirme Formu ile elde edilen verilere göre, Eskişehir İl Halk Kütüphanesi dermesindeki resimli çocuk kitaplarının:

- \%63,1'nin basım bilgisi bulunmakta, \%36,9'nun ise bulunmamaktadır.

- \%24,6's1 16 sayfa ve altında, \%33,8'i 17-24 sayfa aralığında, \%34,6's1 ise 25-32 sayfa aralığından oluşmaktadır.

- $\quad \% 55,4$ 'ü özgün, \%44,6'sı çeviridir.

- \%80'inde yazar tanıtım sayfası, \%84,6'sında kitabın resimleyen adı bulunmamaktadir. 
Eskişehir İl Halk Kütüphanesi Dermesinde Bulunan Resimli Çocuk Kitaplarının Fiziksel ve İçerik Özelliklerinin Ödünç Alınma Üzerinde Etkisi

The Effect of Physical and Content Characteristics of Illustrated Children's Books in the Eskişehir Provincial

- \%64,6's1 büyük boyutlu (kucak boy), \%33,8'i orta boy ve \%1,5'i küçük boyutlu, $\% 58,5$ 'i dikdörtgen ve $\% 41,5$ 'i kare biçimindedir.

- \%87,7'si ince karton kapaklıdir.

- \%54,6'sının kapak görsel etkisi çekici değildir ve \%28'5 oranında kitabın da kapak resimleri içeriği temsil edebilecek nitelikler taşımamaktadır.

- $\quad \% 96,2$ 'si uygun yazı puntosuna, \%86,9'u uygun sayfa düzenine ve $\% 65,4$ 'i uygun resim ve metin oranına sahiptir.

- \%70’inin teması çocuğun yaş grubuna uygundur.

- \%22,3'ündeki kurgu çocuklarda heyecan ve merak duygusu uyandıracak nitelikte değildir.

- \%84,6'sında kahramanlar çocuklar için olumsuz model oluşturmamakta ve \%80'inde olaylar tutarlı bir şekilde ilerlemektedir.

- \%97,7'si genel olarak çocuğun ilgi ve gereksinimlerini karşılayacak nitelikte ve gelişim düzeylerine uygun görünürken, sadece $\% 2,3$ 'ü uygun değildir.

Yukarıda özetlenen verilere dayanarak Eskişehir İl Halk Kütüphanesinde (Eskişehir İHK) yer alan çocuk kitaplarının genelde uygun fiziksel ve içerik özelliklerinin olduğu söylenebilir.

Çalışmada resimli çocuk kitaplarının fiziksel ve içerik özelliklerinin onların ödünç alınma durumlarını nasıl etkilediği de önemli görülmüş ve incelenmiştir. Bu bağlamda ilk olarak Tablo 2'de Eskişehir İHK dermesinde bulunan resimli çocuk kitaplarının yıllık ödünç alınma durumları ile ilgili veriler yer almaktadır.

Tablo 2

Resimli çocuk kitaplarının yıllık ödünç alınma sıklıkları

\begin{tabular}{lrr}
\hline Ödünç alınma sıklı̆̆ (Yıllık ortalama) & $\mathrm{N}$ & $\%$ \\
\hline Hiç alınmamış & 15 & 11,5 \\
$1-3 \mathrm{kez}$ & 79 & 60,8 \\
$4-6 \mathrm{kez}$ & 21 & 16,2 \\
$7+\mathrm{kez}$ & 15 & 11,5 \\
\hline Toplam & 130 & 100 \\
\hline
\end{tabular}

İncelenen kitaplar kullanıcılar (üye okuyucular) tarafından yılda ortalama 2,9 kez ödünç alınmıştır. En yüksek ödünç alınmanın 1-3 kez sıklığında olduğu anlaşılmaktadır $(\% 60,8)$. Ortalamanın üzerinde (4 kez ve daha fazla) ödünç alınma oranı \%27,7'dir. Çalışmada değerlendirilen resimli çocuk kitaplarının çok büyük bir bölümü $(\% 88,5)$ yılda 1 kez ya da daha fazla ödünç alınmıştır. Ödünç alınmayan kitapların oranı sadece \%11,5'tir. Bu veriler, incelenen dermenin canlı ve kullanışlı bir niteliğe sahip olduğu biçiminde yorumlanabilir.

Araştırmada, kitapların üzerlerinde basım bilgisine sahip olması ile ödünç alınma sıklıkları arasında nasıl bir ilişki olduğu da incelenmiştir. Kitaplarda basım bilgisinin olması genellikle çok okunduğu ve bunlara yönelik bir okuyucu talebinin olduğu biçiminde değerlendirilebilir. Tablo 3 ’te konuya ilişkin veriler sunulmuştur. 
Tablo 3

Kitapta basım bilgisi bulunmasının ödünç alınma üzerine etkisi

\begin{tabular}{|c|c|c|c|c|c|c|c|c|c|}
\hline \multirow{3}{*}{$\begin{array}{l}\text { Ödünç alınma } \\
\text { ortalama) }\end{array}$} & \multirow{3}{*}{ s1klığ1 } & \multicolumn{8}{|c|}{ Basim bilgisi } \\
\hline & & \multicolumn{2}{|c|}{ Basım bilgisi yok } & \multicolumn{2}{|c|}{ 1. bs. } & \multicolumn{2}{|c|}{$2+b s$} & \multicolumn{2}{|c|}{ Toplam } \\
\hline & & $N$ & $\%$ & $N$ & $\%$ & $N$ & $\%$ & $N$ & $\%$ \\
\hline Hiç alınmamış & & 9 & 18,7 & 3 & 6,1 & 3 & 9,1 & 15 & 11,5 \\
\hline $1-3 \mathrm{kez}$ & & 32 & 66,7 & 27 & 55,1 & 20 & 60,6 & 79 & 60,8 \\
\hline $4-6 \mathrm{kez}$ & & 6 & 12,5 & 10 & 20,4 & 5 & 15,1 & 21 & 16,2 \\
\hline $7+\mathrm{kez}$ & & 1 & 2,1 & 9 & 18,4 & 5 & 15,1 & 15 & 11,5 \\
\hline Toplam & & 48 & 100 & 49 & 100 & 33 & $99,9 * *$ & 130 & 100 \\
\hline
\end{tabular}

$* \chi 2(6)=11,153, \mathrm{p}=, 084$

**Yuvarlama hatasından dolayı toplam 100'den farklı çıkmaktadır.

Tablo 3 verilerine genel olarak bakıldığında, üzerinde basım bilgisi bulunan ve bulunmayan resimli çocuk kitaplarında ödünç alınma durumunun "Yılda 1-3 kez" aralığında yoğunlaştığı anlaşılmaktadır. Tüm sıklıklar itibariyle ise basım bilgisine sahip olmayan kitapların \%81,3'ü, 1. bs. bilgisi olan kitapların \%93,9'u ve 2+ bs. bilgisi olan kitapların da \%90,8'i yılda en az $1 \mathrm{kez}$ ve daha fazla ödünç alınmıştır. Bulgulara ilişkin bir başka değerlendirme "hiç ödünç alınmama" ve "sık ödünç alınma" aralıkları üzerinden yapılabilir. Buna göre, 2. ve daha üst basım bilgisi bulunan resimli çocuk kitaplarının \%9,1'i hiç ödünç alınmazken, bu oran basım bilgisi olmayan kitaplar için \%18,7'ye çıkmaktadır. Aynı biçimde 2. ve daha üst basım bilgisi olan resimli çocuk kitaplarının $\% 15,1$ 'i yılda ortalama 7 kez ve daha fazla ödünç alınmakta, ancak bu oran basım bilgisi olmayan kitaplar için \%2,1'de kalmaktadır. $\mathrm{Bu}$ karşılaştırmalar temelinde elde edilen bulgulara göre, resimli çocuk kitaplarında basım bilgisi olmasının ödünç almayı belirli ölçüde olumlu yönde etkilediği söylenebilir. Ancak bu etki istatistiksel açıdan anlamlı düzeyde bulunmamıştır. Bir başka deyişle, Eskişehir İHK'ndeki resimli çocuk kitaplarının yıllık ödünç alınma sıklıkları ile basım bilgisi bulunması arasında istatistiksel olarak anlamlı bir ilişki yoktur $(\chi 2(6)=11,153, p=0,084)$. Bir başka deyişle, kitaplarda basım bilgisinin bulunmasının ödünç alma üzerinde etkili olmadığ anlaşılmıştır.

Çalışmada, resimli çocuk kitaplarının ödünç alınma sıklıkları ile kapak türleri arasında nasıl bir ilişki olduğu da incelenmiştir. Tablo 4 bu konudaki verileri sunmaktadır.

\section{Tablo 4}

Kitabın kapak türünün yıllık ödünç alınma sıklı̆̆ üzerine etkisi

\begin{tabular}{lcrrrrr}
\hline & \multicolumn{2}{c}{ Ince karton } & \multicolumn{2}{c}{ Kalın karton } & \multicolumn{2}{c}{ Toplam } \\
\cline { 2 - 7 } Ödünç alınma sıklı̆̆g (Yıllık ortalama) & $N$ & $\%$ & $N$ & $\%$ & $N$ & $\%$ \\
\hline Hiç alınmamış & 14 & 12,3 & 1 & 6,3 & 15 & 11,5 \\
1-3 kez & 79 & 69,3 & - & - & 79 & 60,8 \\
4-6 kez & 15 & 13,1 & 6 & 37,5 & 21 & 16,2 \\
7+ kez & 6 & 5,3 & 9 & 56,2 & 15 & 11,5 \\
\hline Toplam & 114 & 100 & 16 & 100 & 130 & 100 \\
\hline
\end{tabular}

$* \chi 2(3)=48,288, p=, 000$ 
Eskişehir İl Halk Kütüphanesi Dermesinde Bulunan Resimli Çocuk Kitaplarının Fiziksel ve İçerik Özelliklerinin Ödünç Alınma Üzerinde Etkisi

The Effect of Physical and Content Characteristics of Illustrated Children's Books in the Eskişehir Provincial

Tablo 4 verilerine göre, ince karton kapaklı kitaplarda ödünç alınma "Yılda 1-3 kez" sıklığında yoğunlaşırken $(\% 69,3)$, kalın karton kapaklı kitaplarda yoğunlaşma "Yılda 7+" sıklığında $(\% 56,2)$ gerçekleşmiştir. Genel olarak tüm sıklıklar ele alındığında ince karton kapağa sahip resimli çocuk kitaplarının \%87,7'sinin, kalın karton kapaklı kitapların ise \%93,7'sinin yılda en $1 \mathrm{kez}$ ve daha fazla ödünç alındığ 1 görülmektedir. Ancak kalın karton kapaklı kitapların \%56,2'si yılda ortalama 7 kez ve daha fazla ödünç alınırken, bu oran ince kartonlu kapağa sahip kitaplar için yaklaşık on kat farkla sadece \%5,3'tür. Kalın karton kapaklı kitaplar lehine benzer bir farklılık 4-6 kez ödünç alınma sıklığında da görülmektedir. Kalın karton kapaklı kitapların \%37,5'i yılda ortalama 4-6 kez ödünç alınmış, bu oran ince karton kapaklı kitaplar için \%13,1 oranında kalmıştır. Aralarında yaklaşık 3 katlık fark bulunmaktadır. Resimli çocuk kitaplarının kalın ya da ince karton kapağa sahip olmaları ile ödünç alınma sıklıkları arasında istatistiksel olarak da $(\chi 2(3)=48,288, \mathrm{p}=0,000)$ anlamlı bir ilişki bulunmuştur. Gözlemlerimize dayalı olarak kalın kapaklı çocuk kitaplarının anlamlı oranda daha fazla ödünç alınmasının temel nedeninin fiziksel olarak daha sağlam ve çekici olmaları/görünmeleri ile ilgili olduğu söylenebilir. Bir başka önemli neden de ince ve kalın karton kapaklı toplam kitap sayılarıdır. Dermede 114 ince karton kapaklı ve 16 kalın karton kapaklı çocuk kitabı bulunmaktadır. Kalın kapaklı karton kitap sayısı daha yüksek olsaydı karşılaştırma daha açıklayıcı olabilirdi. Ancak kapak türü ile ödünç alınma arasındaki ilişki ve buna yapılan yorum her iki kapak türünün kendi içinde değerlendirilmesi ile ölçüldüğü için istatistiksel açıdan tutarlıdır. ${ }^{5}$

Araştırmada incelenen resimli çocuk kitaplarının özgün (Türkçe yazılmış) ya da çeviri olmalarının ödünç almayı nasıl etkilediği de değerlendirilmiştir. İlgili veriler Tablo 5 'tedir.

Tablo 5

Kitabın özgün ya da çeviri olmasının yıllık ödünç alınma sıklı̆̆ı üzerine etkisi

\begin{tabular}{lrrrrrr}
\hline & \multicolumn{2}{c}{ Özgün } & \multicolumn{2}{c}{ Çeviri } & \multicolumn{2}{c}{ Toplam } \\
\cline { 2 - 8 } Ödünç alınma sıklı̆̆ı (Yıllık ortalama) & $N$ & $\%$ & $N$ & $\%$ & $N$ & $\%$ \\
\hline Hiç alınmamış & 13 & 18,1 & 2 & 3,4 & 15 & 11,5 \\
$1-3 \mathrm{kez}$ & 46 & 63,9 & 33 & 56,9 & 79 & 60,8 \\
$4-6 \mathrm{kez}$ & 9 & 12,5 & 12 & 20,7 & 21 & 16,2 \\
$7+$ kez & 4 & 5,5 & 11 & 19,0 & 15 & 11,5 \\
\hline Toplam & 72 & 100 & 58 & 100 & 130 & 100 \\
\hline
\end{tabular}

$* \chi 2(3)=12,539, \mathrm{p}=, 006$

Tablo 5 verilerine genel olarak bakıldığında, her iki kitap türü için de ödünç almanın "Yılda 1-3 kez" aralığında yoğunlaştığı, tüm ödünç alma sıklıkları itibariyle özgün çocuk kitaplarının \%81,9'unun, çeviri çocuk kitaplarının ise \%96,6'sının ödünç alındığ1 anlaşılmaktadır. Çeviri resimli çocuk kitapları özgün kitaplara göre yaklaşı \% 15 oranında daha çok ödünç alınmıştır. Bu iki tür arasında ödünç alınma açısından asıl farklılığın yoğunlaştığı sıklıklar ise "hiç ödünç alınmama" ve "Yılda 7+ kez" sıklıklarıdır. Özgün resimli çocuk

\footnotetext{
${ }^{5}$ Toplam sayıları birbirinden çok farklı (114 ve 16) olduğu için türlerin birbiriyle doğrudan karşılaştırılarak değerlendirilmesi anlamlı görülmediği için her kitap türünün ödünç alınma oranları kendi içinde hesaplanmıştır. Bu durum ve açıklama bundan sonra benzer veri farklılıkları içeren tablolar için de geçerlidir.
} 
kitaplarının \%18,1'i hiç ödünç alınmazken, bu oran çeviri kitaplar için sadece \%3,4’tür. Bu iki kitap türünün arasındaki ödünç alınma sıklığı farkı $7 \mathrm{kez}$ ve daha fazla aralığında da görülmektedir. Özgün resimli çocuk kitaplarının \%5,6'sı yılda ortalama 7 kez ve üzerinde ödünç alınırken, çeviri kitapların \%19’u bu sıklıkla ödünç alınmaktadır. Aradaki fark dört kata yakın görünmektedir. Veriler temelinde yapılan ki-kare analizi sonucunda da Eskişehir İHK dermesinde bulunan ve araştırma kapsamına alınan resimli çocuk kitaplarının özgün ya da çeviri niteliğinde olmasının, onların ödünç alınma sıklıklarını istatistiksel olarak anlamlı düzeyde etkilediği ortaya çıkmıştır $(\chi 2(3)=12,539, p=0,006)$. Bu etki, birbirine yakın oranlar gibi görünse de özellikle "hiç ödünç alınmama" ve “sık (7+ kez) ödünç alınma” sıklıkları bağlamında çeviri çocuk kitaplarının daha çok ödünç alınması yönündedir. İstatistiksel olarak da ortaya çıkan ve çeviri kitaplar lehine görülen ödünç alınma sıklığı farkının, araştırma sırasında yaptığımız incelemelere de dayanarak çeviri kitapların genel olarak özgün (Türkçe yazılmış) kitaplara göre fiziksel ve içerik özellikleri açısından genel olarak daha iyi durumda olmalarından kaynaklanmış olabileceği değerlendirilmiştir.

Resimli çocuk kitaplarının boyutlarının ödünç alma sıklıklarını nasıl etkilediği araştırma kapsamına alınan konulardan birisidir. Elde edilen veriler Tablo 6'da sunulmuştur.

\section{Tablo 6}

Kitabın boyutunun ödünç alınma sıklı̆̆̆ üzerine etkisi

\begin{tabular}{|c|c|c|c|c|c|c|c|c|}
\hline \multirow[b]{3}{*}{ Ödünç alınma sıklığı (Y1llık ortalama) } & \multicolumn{8}{|c|}{ Kitabın boyutu } \\
\hline & \multicolumn{2}{|c|}{ Büyük } & \multicolumn{2}{|c|}{ Orta } & \multicolumn{2}{|c|}{ Küçük } & \multicolumn{2}{|c|}{ Toplam } \\
\hline & $N$ & $\%$ & $N$ & $\%$ & $N$ & $\%$ & $N$ & $\%$ \\
\hline Hiç alınmamış & 8 & 9,5 & 7 & 15,9 & - & - & 15 & 11,5 \\
\hline $1-3 \mathrm{kez}$ & 47 & 56,0 & 30 & 68,2 & 2 & 100 & 79 & 60,8 \\
\hline $4-6 \mathrm{kez}$ & 15 & 17,9 & 6 & 13,6 & - & - & 21 & 16,2 \\
\hline $7+\mathrm{kez}$ & 14 & 16,7 & 1 & 2,3 & - & - & 15 & 11,5 \\
\hline Toplam & 84 & $101 * *$ & 44 & 100 & 2 & 100 & 130 & 100 \\
\hline
\end{tabular}

$* \chi 2(6)=8,546, \mathrm{p}=, 201$

**Yuvarlama hatasından dolayı toplam 100'den farklı çıkmaktadır.

Tablo 6 verilerine genel olarak bakıldığında, gerek büyük ve gerekse orta boyutlu kitaplarda ödünç alınma oranlarının birbirine yakın olduğu $(\% 56, \% 68,2)$ ve ödünç alınmanın "Yılda 1-3 kez" sıklığında yoğunlaştığı anlaşılmaktadır. Burada küçük boyutlu sadece 2 kitap olduğundan oranı \%100 olsa da değerlendirmeye almak uygun olmayacaktır. Tüm ödünç alınma sıklıkları bağlamında ise büyük boy çocuk kitaplarının \%90,6'sının, orta boyutlu kitapların \%84,1'inin ve küçük boy kitapların ise tümünün ödünç alındığı görülmektedir. Sunulan bazı oransal farklılıklara karşın, elde edilen verilere ve yapılan istatistiksel analize göre, resimli çocuk kitaplarında boyut ödünç almayı istatistiksel olarak anlamlı oranda etkileyen bir fiziksel özellik değildir. Bir başka deyişle, kitap boyutu ile ödünç alınma sıklığ1 arasında istatistiksel açıdan anlamlı bir ilişki bulunamamıştır $(\chi 2(6)=8,546, p=0,201)$. Her üç kitap türü toplam sayılarının birbirinden büyük ölçüde farklı ve özellikle küçük boy çocuk kitabı sayısının sadece 2 olması değerlendirme için sınırlılık durumu yaratsa da her kitap türü ödünç alınma açısından kendi içinde oranlandığından istatistiksel olarak ve dolayısıyla yorum itibariyle bir tutarsızlık söz konusu değildir. İstatistiksel olarak anlamlı olmasa da araştırma verilerine özellikle "Yılda 7+ kez" ödünç alınma sıklığı bağlamında bakıldığında, kitap 
Eskişehir İl Halk Kütüphanesi Dermesinde Bulunan Resimli Çocuk Kitaplarının Fiziksel ve İçerik Özelliklerinin Ödünç Alınma Üzerinde Etkisi

The Effect of Physical and Content Characteristics of Illustrated Children's Books in the Eskişehir Provincial

türlerinin ödünç alınma durumları arasında farklılıklar olduğu görülmektedir. Buna göre, büyük boyutlu çocuk kitaplarının \%16,7'si sık (yılda ortalama 7 kez ve daha fazla) ödünç alınırken, orta boy kitapların \%2,3'ü sık ödünç alınmaktadır. Küçük boy kitaplar arasında yılda ortalama 7 kez ve daha fazla ödünç alınan kitap bulunmamaktadır.

Çocuk kitaplarında yer alıp almaması konusunda farklı yaklaşımların olduğu unsurlardan birisi de kitabın hitap ettiği yaş grubu bilgisidir. Çalışmada resimli çocuk kitaplarının yaş bilgisine sahip olup olmamalarının ödünç alma üzerine etkisi incelenmiştir. Elde edilen veriler Tablo 7'de sunulmuştur.

Tablo 7

Kitapta yaş grubu bilgisi olmasının yıllık ödünç alınma sıklı̆̆ üzerine etkisi

\begin{tabular}{|c|c|c|c|c|c|c|c|c|}
\hline \multirow[b]{3}{*}{ Ödünç alınma sıklığı (Y1llık ortalama) } & \multicolumn{8}{|c|}{ Yaş grubu } \\
\hline & \multicolumn{2}{|c|}{ Belirtilmiş } & \multicolumn{2}{|c|}{ Belirtilmemiş } & \multicolumn{2}{|c|}{ Diğer } & \multicolumn{2}{|c|}{ Toplam } \\
\hline & $N$ & $\%$ & $N$ & $\%$ & $N$ & $\%$ & $N$ & $\%$ \\
\hline Hiç alınmamış & 1 & 6,7 & 14 & 13,7 & - & - & 15 & 11,5 \\
\hline $1-3 \mathrm{kez}$ & 9 & 60,0 & 61 & 59,8 & 9 & 69,3 & 79 & 60,8 \\
\hline 4-6 kez & 3 & 20,0 & 15 & 14,7 & 3 & 23,0 & 21 & 16,2 \\
\hline $7+\mathrm{kez}$ & 2 & 13,3 & 12 & 11,8 & 1 & 7,7 & 15 & 11,5 \\
\hline Toplam & 15 & 100 & 102 & 100 & 13 & 100 & 130 & 100 \\
\hline
\end{tabular}

$* \chi 2(6)=3,270, \mathrm{p}=, 774$

Tablo 7 verilerine göre, üzerinde yaş grubu bilgisi belirtilen ya da belirtilmeyen resimli çocuk kitaplarında ödünç alma yoğunluğunun "Yılda 1-3 kez" sıklığında olduğu (\%60 ve \%59,8) ve ödünç alma oranlarının üç tür kitaplar için de tüm sıklıklarda birbirine yakın göründüğü söylenebilir. Bu oranlar, örneğin "Yılda 4-6 kez" ya da "Yılda 7+ kez" sıklıklarında da çok farklı değildir. Buna göre, üzerinde hitap edilen yaş grubu bilgisi olan ve olmayan resimli çocuk kitaplarının yılda ortalama $7 \mathrm{kez}$ ve daha fazla ödünç alınma oraları \%13,3 ve \%11,8, "Yılda 4-6 kez" ödünç alınma sıklık oranları da \%20 ve \%14,7'dir. Bu yakınlık istatistiksel olarak da ortaya çıkarılmış ve yapılan ki-kare analizinde kitaplarda yaş grubu bilgisi olması-olmaması ile ödünç alınma sıklıkları arasında istatistiksel açıdan anlamlı bir ilişki bulunamamıştır $(\chi 2(6)=3,270, p=0,774)$. Tablo 7'de yer alan ve "Diğer" seçeneği altında görünen toplam 13 kitap net bir yaş grubu bilgisi yazılmadığı için bu grupta değerlendirilmiştir. Bu kitapların üzerinde "7 yaşına kadar çocuğa ebeveyn okuyabilir, 7 yaşından sonra çocuk kendi okuyabilir” şeklinde ifadeler yer almaktadır. Bu tablo verilerine ilişkin olarak burada genel olarak belirtilmesi gereken önemli nokta, araştırma kapsamında incelenen resimli çocuk kitaplarının çok büyük bir bölümünde yaş grubu bilgisinin bulunmadığı ve bunun daha önceki benzer tablo değerlendirmelerinde vurgulandığg üzere aktarılan istatistiksel sonucun olası nedeni olabileceğidir.

Resimli çocuk kitaplarında kitapla okuyucu arasındaki ilk ilişkiyi sağlayan kitap kapağının görsel etkisi genellikle kabul edilen bir gerçektir. Çalışmada bu konuda da ele alınmış ve ödünç almaya etkisi değerlendirilmiştir. İlgili veriler Tablo 8'de yer almaktadır. 


\section{Tablo 8}

Kitap kapă̆ı görsel niteliğinin ödünç alınma sıklı̆̆ üzerine etkisi

\begin{tabular}{lrrrrrr}
\hline & \multicolumn{3}{c}{ Kapağın görsel etkisi ilgi çekici mi? } \\
\cline { 2 - 7 } Ödünç alınma sıklığı (Yıllık ortalama) & \multicolumn{2}{c}{ Evet } & \multicolumn{3}{c}{ Hayır } & \multicolumn{2}{c}{ Toplam } \\
\cline { 2 - 7 } & \multicolumn{1}{c}{$N$} & $\%$ & $N$ & $\%$ & $N$ & $\%$ \\
\hline Hiç alınmamış & 2 & 3,4 & 13 & 18,3 & 15 & 11,5 \\
$1-3$ kez & 29 & 49,2 & 50 & 70,4 & 79 & 60,8 \\
4-6 kez & 13 & 22,0 & 8 & 11,3 & 21 & 16,2 \\
$7+$ kez & 15 & 25,4 & - & - & 15 & 11,5 \\
\hline Toplam & 59 & 100 & 71 & 100 & 130 & 100 \\
\hline
\end{tabular}

$* \chi 2(3)=28,979, p=, 000$

Tablo 8'de yansıtılan verilere bakıldığında, kapağı görsel açıdan çekici olan ve olmayan resimli çocuk kitaplarının her iki grubunda da ödünç alma durumunun "Yılda 1-3 kez" sıklığında yoğunlaştığı $(\% 49,2$ ve \%70,4) görülmektedir. Ödünç alınma durumu genel olarak değerlendirildiğinde, kapağının görsel çekiciliği olan resimli çocuk kitaplarının \%96,6'sı ödünç alınırken, bu oranın kapağı görsel açıdan çekici olmayan kitaplar için \%81,7'ye düştüğü anlaşılmaktadır. Araştırmaya dâhil edilen resimli çocuk kitaplarının sık ödünç alınma ve hiç ödünç alınmama sıklıklarına bakıldığında ise, kapağa ilişkin görsel çekiciliğin ödünç alma üzerindeki etkisi daha açı bir biçimde görülmektedir. Buna göre, kapağı görsel açıdan çekici olmayan resimli çocuk kitaplarının hiçbirisi sık (yılda ortalama 7 kez ve daha fazla) olarak ödünç alınmamıştır. Buna karşın, kapak tasarımı görsel çekiciliğe sahip resimli çocuk kitaplarının dörtte biri $(\% 25,4)$ yılda ortalama $7 \mathrm{kez}$ ve daha fazla ödünç alınmıştır. Benzer farklılık "hiç ödünç alınmama" sıklığı için de geçerli görünmektedir. Buna göre, kapağı görsel açıdan çekici olmayan resimli çocuk kitaplarının \%18,3’ü hiç ödünç alınmazken, bu oran çekici kapak görseline sahip resimli çocuk kitaplarında \%3,4’tür. Ele alınan konuya ilişkin olarak yapılan ki-kare analizi sonucunda da kapak görsel tasarımının çekici olması-olmaması ile ödünç alınma arasında istatistiksel olarak anlamlı ilişki saptanmıştır $(\chi 2(3)=28,979, p=0,000)$. Kısaca belirtmek gerekirse, resimli çocuk kitaplarında kapak tasarımı okuyucuyu kitap seçme, ödünç alma ve okumada etkileyen bir unsurdur.

Bu çalışmada tablo biçiminde yansıtılmamasına karşın, elde edilen diğer verilere göre:

- Resimli çocuk kitap kapaklarının içeriği yansıtıp-yansıtmaması ile ödünç alınma sıklıkları arasında istatistiksel olarak anlamlı bir ilişki vardır $(\chi 2(3)=10,912, p=0,012)$.

- Resimli çocuk kitaplarındaki resimlerin çocuğun öykü oluşturmasını sağlayacak nitelikte olması da ödünç alınmayı anlamlı düzeyde olumlu etkilemektedir $(\chi 2(3)=18,930, p=0,000)$. Başka bir deyişle, resimleri kendi başına öykü oluşturmayı sağlayan çocuk kitapları anlamlı oranda daha fazla ödünç alınmaktadır.

- Resimli çocuk kitaplarında yer alan resimlerin metinle uyumlu olması (resim-metin uyumu) da ödünç almayı istatistiksel olarak anlamlı oranda etkilemektedir $(\chi 2(3)=19,341, \mathrm{p}=0,000)$.

- Kitaplardaki temanın ödünç alma durumunu nasıl etkilediği elde edilen veriler çerçevesinde incelenmiş ve istatistiksel olarak tema ile ödünç alma sıklığı arasında anlamlı bir ilişki bulunmamıştır $(\chi 2(6)=6,416, p=0,378)$. 
Eskişehir İl Halk Kütüphanesi Dermesinde Bulunan Resimli Çocuk Kitaplarının Fiziksel ve İçerik Özelliklerinin Ödünç Alınma Üzerinde Etkisi

The Effect of Physical and Content Characteristics of Illustrated Children's Books in the Eskişehir Provincial

Araştırmada resimli çocuk kitaplarının çocukların gelişim düzeyine uygun olup olmaması ile ödünç alma sıklıkları arasındaki ilişkiyi incelemek özellikle araştırma hipotezi açısından önemli bulunmuştur. Bu konuya yönelik olarak elde edilen veriler aşağıda (Tablo 9) verilmiştir.

Tablo 9

Kitabın çocukların gelişim düzeyine, ilgi ve gereksinimlerine uygunluğunun ödünç alınma üzerine etkisi

\begin{tabular}{|c|c|c|c|c|c|c|c|c|}
\hline \multirow[b]{3}{*}{ Ödünç alınma sıklığı (Yıllık ortalama) } & \multicolumn{8}{|c|}{ Çocukların gelişim düzeyine uygun mu? } \\
\hline & \multicolumn{2}{|c|}{ Evet } & \multicolumn{2}{|c|}{ Kismen } & \multicolumn{2}{|c|}{ Hayır } & \multicolumn{2}{|c|}{ Toplam } \\
\hline & $N$ & $\%$ & $N$ & $\%$ & $N$ & $\%$ & $N$ & $\%$ \\
\hline Hiç alınmamış & 4 & 5,4 & 10 & 18,9 & 1 & 33,3 & 15 & 11,5 \\
\hline $1-3 \mathrm{kez}$ & 44 & 59,5 & 33 & 62,3 & 2 & 66,7 & 79 & 60,8 \\
\hline 4-6 kez & 11 & 14,9 & 10 & 18,9 & - & - & 21 & 16,2 \\
\hline $7+\mathrm{kez}$ & 15 & 20,3 & - & - & - & - & 15 & 11,5 \\
\hline Toplam & 74 & $101 * *$ & 53 & $101 * *$ & 3 & 100 & 130 & 100 \\
\hline
\end{tabular}

${ }^{*} \chi 2(6)=18,326, \mathrm{p}=, 005$

**Yuvarlama hatasından dolayı toplam 100'den farklı çıkmaktadır.

Tablo 9'a genel olarak bakıldığında, Eskişehir İHK dermesinde bulunan ve örnekleme alınan resimli çocuk kitaplarının çocukların gelişim düzeyine uygun olup olmasının ödünç almayı ciddi oranda etkilediği görülmektedir. Çocuğa göre olan kitapların tüm sıklıklar itibariyle \%94,7'si ödünç alınırken, çocuğun gelişimine uygun olmadığı belirlenen kitaplarda ödünç alınma oranı \%66,7'ye, kısmen uygun olanlarda ise \%81,2'ye düşmektedir. Her üç grup kitapta da ödünç alınmanın yoğunlaştığı sıklık "Yılda 1-3 kez"dir. Ödünç alınma durumuna sık ödünç alınma ile hiç ödünç alınmama açısından bakmakta da yarar bulunmaktadır. Çocuğa göre (uygun) olan resimli çocuk kitaplarının \%20,3'ü sık (7+ kez) ödünç alınırken, çocuk gelişimine kısmen uygun olan ya da hiç uygun olmayan kitapların hiçbiri sık ödünç alınmamıştır. Benzer ödünç alınma farklılıkları "Hiç alınmamış" sıklığında da görülmektedir. Çocukların gelişimine uygun olan resimli çocuk kitaplarının sadece \%5,4’ü hiç ödünç alınmazken, çocuğa kısmen uygun olan kitapların ödünç alınmama oranı \% 18,9 (yaklaşık dört kat fazla), hiç uygun olmayan kitapların ise \%33,3'tür (yaklaşık altı kat fazladır). Yapılan ki-kare analiz sonucunda ödünç alınma ile resimli çocuk kitaplarının çocuğa uygun olup olmaması arasında istatistiksel olarak anlamlı ilişki saptanmıştır $(\chi 2(6)=18,326, p=0,005)$. Bu bulgu çalışma hipotezini doğrudan kanitlar niteliktedir.

Çalışma hipotezine yönelik bir başka inceleme konusu da resimli çocuk kitaplarının çocukta okuma isteği uyandıracak nitelikte olup olması ile ödünç alınma sıklığı arasındaki ilişkidir. Bu konuda elde edilen veriler Tablo 10'da görülmektedir. 
Tablo 10

Kitabın çocukta okuma isteği uyandıracak nitelikte olmasının yıllık ödünç alınma üzerine etkisi

\begin{tabular}{|c|c|c|c|c|c|c|c|c|}
\hline \multirow[b]{3}{*}{ Ödünç alınma sıklığı (Yıllık ortalama) } & \multicolumn{8}{|c|}{ Çocukta okuma isteği uyandırıyor mu? } \\
\hline & \multicolumn{2}{|c|}{ Evet } & \multicolumn{2}{|c|}{ Kismen } & \multicolumn{2}{|c|}{ Hayır } & \multicolumn{2}{|c|}{ Toplam } \\
\hline & $N$ & $\%$ & $N$ & $\%$ & $N$ & $\%$ & $N$ & $\%$ \\
\hline Hiç alınmamış & 1 & 1,8 & 4 & 10,5 & 10 & 27,8 & 15 & 11,5 \\
\hline $1-3 \mathrm{kez}$ & 27 & 48,2 & 28 & 73,7 & 24 & 66,7 & 79 & 60,8 \\
\hline $4-6 \mathrm{kez}$ & 13 & 23,2 & 6 & 15,8 & 2 & 5,6 & 21 & 16,2 \\
\hline $7+\mathrm{kez}$ & 15 & 26,8 & - & - & - & - & 15 & 11,5 \\
\hline Toplam & 56 & 100 & 38 & 100 & 36 & $101^{* *}$ & 130 & 100 \\
\hline
\end{tabular}

$* \chi 2(6)=39,635, \mathrm{p}=, 000$

**Yuvarlama hatasından dolayı toplam 100'den farklı çıkmaktadır.

Tablo 10 verilerine genel olarak bakıldığında, Eskişehir İHK dermesinde bulunan ve çocukta okuma isteği uyandıracak nitelikte olan resimli çocuk kitaplarının \%98,2'si, kısmen bu nitelikte olanların \%89,5 ve niteliksiz çocuk kitaplarının da \%72,3'ü yılda en az 1 kez ödünç alınmıştır. Ödünç alınma her üç grup kitapta da "Yılda 1-3 kez" aralığında yoğunlaşmıştır. Söz konusu kitap grupları arasındaki karşılaştırma sık ödünç alınma ve hiç ödünç alınmama durumları üzerinden değerlendirildiğinde daha belirgin farklılıklar görülebilmektedir. Buna göre, çocukta okuma isteği uyandıracak nitelikte olan resimli çocuk kitaplarının \%26,8'i sık (yıllık ortalama $7 \mathrm{kez}$ ve daha fazla) ödünç alınmış, buna karşın bu nitelikte olmayan çocuk kitaplarının hiçbiri sık olarak ödünç alınmamıştır. Benzer biçimde nitelikli kitapların yarısı (\%50) genel ortalamanın üzerinde (yılda 4 kez ve daha fazla) ödünç alınırken, bu oran niteliksiz kitaplarda \%5,6 oranında kalmıştır. Arada sekiz kattan fazla fark bulunmaktadır. Okuma isteği uyandırmayan nitelikteki kitapların hiç ödünç alınmama oranı \%27,8 olmuş, nitelikli kitapların ise sadece \%1,8'i hiç ödünç alınmamıştır. Burada yapılan karşılaştırmalar ki-kare analizi ile de sınanmış ve ödünç alınma oranları açısından nitelikli (çocukta okuma isteği uyandıran) çocuk kitapları ile niteliksiz çocuk kitapları arasında ödünç alınmaları açısından istatistiksel olarak anlamlı düzeyde fark bulunmuştur $(\chi 2(6)=39,635, \mathrm{p}=0,000)$. Bu bulgu bir önceki tabloda (Tablo 9) olduğu gibi çalışma hipotezini kanıtlar niteliktedir.

Çalışma bulgularına ilişkin bir özet olması açısından, Eskişehir İHK dermesinde bulunan ve örneklem çerçevesinde incelenen resimli çocuk kitaplarının fiziksel-içerik özellikleri ve çocuğa görelik durumları ile ödünç alınmaları arasında istatistiksel olarak anlamlı ilişki bulunan ve bulunmayan unsurlara ilişkin veriler bir arada görülebilmesi için Tablo 11 'de sunulmuştur. 
Eskişehir İl Halk Kütüphanesi Dermesinde Bulunan Resimli Çocuk Kitaplarının Fiziksel ve İçerik Özelliklerinin Ödünç Alınma Üzerinde Etkisi

The Effect of Physical and Content Characteristics of Illustrated Children's Books in the Eskișehir Provincial

Public Library's Collections on Borrowing

\section{Tablo 11}

Kitapların fiziksel-içerik özellikleri ve çocuğa görelik unsurlarının ödünç alınma üzerine etkisi

\begin{tabular}{lrr}
\hline Kitapların fiziksel-içerik özellikleri ve çocuğa görelik unsurları & \multicolumn{2}{c}{ Ödünç alınma ile anlamlı ilişkisi } \\
\cline { 2 - 3 } & Var & Yok \\
\hline Kitap basım bilgisinin olup olmaması & + & + \\
Kitap kapak türü & + & + \\
Kitabın özgün (Türkçe yazılmış) ya da çeviri olma durumu & & + \\
Kitap boyutu & & + \\
Kitap biçimi & + \\
Kitapta yaş grubu bilgisinin olup-olmaması & + \\
Kitap kapağının görsel açıdan ilgi çekici olup-olmaması & + \\
Kitap kapak resminin konuyu yansıtıp yansıtmaması & + \\
Kitapta yer alan resimleri çocuğun öykü oluşturabileceği nitelikte olması & \\
Kitapta resim ve metin oranının uyumu & + \\
Kitap temasının çocuğun yaş grubuna uygun olup olmaması & + \\
Kitabın çocuğun gelişim düzeyine uygun olup olmaması & + \\
Kitabın çocukta okuma isteği uyandıracak nitelikte olup-olmaması & \\
\hline
\end{tabular}

Eskişehir İHK dermesinde bulunan resimli çocuk kitaplarının ödünç alınmasını olumlu ya da olumsuz yönde etkileyen birçok fiziksel ve içerik özelliği/unsuru bulunmuştur. Tablo 11 verilerine göre kitap kapağı, kitabın özgün ya da çeviri olması, kapak görsel etkisinin çekiciliği, kapak resminin içeriği yansıtması, kitap resimlerinin çocuğun öykü oluşturabileceği nitelikte olması, kitaptaki resim-metin oranının uygunluğu, kitabın çocukların gelişim düzeyine, ilgi ve gereksinimlerine uygunluğu ile kitabın çocukta okuma isteği uyandıracak nitelikte olması resimli çocuk kitaplarının ödünç alınmasını olumlu yönde etkilemektedir. Buna karşılık kitabın boyutu, biçimi, hitap ettiği yaş grubu bilgisinin verilmesi ile kitap temasının çocuğun yaş grubuna uygunluğu unsurları ödünç almada etkili olmamaktadır.

\section{Sonuç ve Öneriler}

Araştırmada Eskişehir İl Halk Kütüphanesi (Eskişehir İHK) dermesinden rastgele örneklemle seçilerek çalışma kapsamına alınan ve bir önceki bölümde bulguları sunulan resimli çocuk kitaplarının fiziksel ve içerik özelliklerinin, kitapların ödünç alınma durumlarını nasıl etkilediğine ilişkin çeşitli sonuçlar elde edilmiştir. Buna göre Eskişehir İHK dermesinde yer alan:

1. Resimli çocuk kitapları genellikle yılda ortalama 1-3 kez ödünç alınmaktadır.

2. Resimli çocuk kitaplarının basım bilgisine sahip olmaları, onların yıllık ödünç alınma sıklıklarını istatistiksel olarak anlamlı ölçüde etkilememektedir.

3. Kitapların kapak türleri ile yıllık ödünç alınma sıklıkları arasında istatistiksel açıdan anlamlı bir ilişki bulunmaktadır. Kalın kartonlu kapağa sahip resimli çocuk kitapları daha çok ödünç alınmaktadır.

4. Resimli çocuk kitaplarının özgün ya da çeviri olması onların yıllık ödünç alınma durumlarını istatistiksel olarak anlamlı düzeyde etkilemektedir. Resimli çocuk kitapları bağlamında özgün kitaplara kıyasla çeviri kitapların genellikle daha uygun dış ve içyapı 
özelliklerine sahip olduğu görülmekte; bu iki gruptaki kitapların ödünç alınma sıklıkları bağlamında çeviri kitaplar lehine olan farklılık bu durumdan kaynaklanmaktadır.

5. Resimli çocuk kitaplarının boyutları ödünç alınmalarını istatistiksel olarak etkilememektedir.

6. Resimli çocuk kitapların üzerinde hitap ettiği yaş grubu bilgisinin yer alması ile ödünç alınma durumları arasında istatistiksel açıdan anlamı bir ilişki bulunamamaktadır.

7. Resimli çocuk kitaplarının kapak görsellerinin çekiciliği, kapak resimlerinin içeriği yansıtması ve resimlerin çocuğun öykü oluşturmasına uygun nitelikte olması, resim ve metin oranı kitapların ödünç alınmalarını istatistiksel olarak anlamlı ölçüde etkilemektedir.

8. Resimli çocuk kitaplarının çocuğa göre (onun gelişim düzeyine uygun) olması onların ödünç alınma durumlarını olumlu yönde etkilemektedir. Çocuğa uygun olan kitaplar anlamlı oranda daha fazla ödünç alınmaktadır.

9. Resimli çocuk kitaplarının temasının çocuğun yaş grubuna uygun olması ödünç alınmayı anlamlı biçimde etkilememektedir.

10. Çocukta okuma isteği uyandıran resimli çocuk kitapları anlamlı biçimde daha çok ödünç alınmaktadır.

Elde edilen sonuçlara dayanarak şu öneriler sunulabilir:

- Eskişehir İHK'ye sağlanacak kitaplar çocuk edebiyatı ve çocuğa görelik ilkeleri çerçevesinde dikkatli bir biçimde ve titizlikle seçilmelidir. Seçim işleminde edebiyat, psikoloji, çocuk gelişimi gibi ilgili konularda çalışan uzmanlardan yardım alınabilir.

- Eskişehir İHK'de çalışan kütüphaneciler çocuk edebiyatı ve çocuk yayıncılığı alanları ile ilgili gelişme, etkinlik ve programları yakından izlemelidir.

- Kütüphaneciler çocuk edebiyatı konusunda bilgili olmalı, bu konuda gerçekleşen kongre, sempozyum, çalıştay vb. bilimsel toplantılara katılmaya çalışmalıdırlar. Ayrıca Eskişehir İHK kendi çalışanlarına yönelik olarak çocuk edebiyatı ve çocuk kitapları konusunda belirli aralıklarla hizmet içi eğitimler düzenlemelidir.

- Kütüphaneciler çocuk kitaplarının seçimi konusunda başka kütüphanelerde çalışan meslektaşlarıyla iletişim içinde olmalı ve onların deneyim ve görüşlerinden yararlanmalı ve bilgi alışverişi içinde olmalıdırlar.

- Eskişehir İHK'de çocuk kitapları dermesi çeşitlendirilmeli ve zenginleştirilmelidir. Basılı kitapların yanı sıra e-çocuk kitapları ve dergileri, sesli kitaplar vb. e-yayınları içeren dijital derme de geliştirilmelidir.

- Kullanıcılar kütüphaneye yeni gelen çocuk kitapları hakkında çeşitli iletişim kanallarıyla bilgilendirilmeli, bu kitapların tanıtımı yapılmalıdır.

- Kütüphanenin çocuk kitapları dermesi sık sık gözden geçirilerek, fiziksel ve içerik özellikleri açısından uygun olmayan kitaplar ayıklanmalı ve derme yeni kitaplarla zenginleştirilmelidir.

- Kütüphaneciler kendilerine Kütüphaneler ve Yayımlar Genel Müdürlüğü (KYGM) tarafından seçilerek gönderilen çocuk kitaplarını titizlikle incelemeli ve olumsuz niteliklere sahip olanlar hakkında ilgili Genel Müdürlüğe geri bildirimde bulunmalidirlar. 
- KYGM, ilgili konu uzmanlarının görüşleri çerçevesinde çocuk kitaplarının seçiminde yol gösterecek ve dayanak oluşturacak çocuk edebiyatı ve çocuğa görelik ilkelerine dayalı nesnel seçim ölçütlerini içeren, Çocuk Yayınları Seçme Yönetmeliği hazırlamalı ve çıkarmalıdır.

- Söz konusu yönetmelik uygulamaya geçirildikten sonra Türkiye'deki halk kütüphaneleri için KYGM tarafından yapılan çocuk kitaplarının seçimi ve sağlanması işlemleri kütüphanelerin sorumluluğuna bırakılmalıdır.

- Eskişehir İHK, ebeveynlere, öğretmenlere ve çocuklara anket uygulamalı, görüşmeler yapmalı ve onlardan resimli çocuk kitapları dermesi hakkındaki düşünce, değerlendirme ve önerileri almalıdır. Bu geri bildirimler derme oluşturma ve geliştirme süreçlerinde mutlaka dikkatle değerlendirilmelidir.

- Kütüphane çocukların, ebeveynlerin ve öğretmenlerin nitelikli çocuk kitabı seçimi yapabilmelerine yardımcı olacak bilgilendirici ve eğitici toplantılar düzenlemelidir. Ayrıca bu konuda basit, pratik ve işlevsel çocuk kitabı seçim kılavuzları hazırlanmalıdır.

- Kütüphanenin çocuk kitapları dermesinin daha çok kullanılması ve ödünç alınması için özellikler kreş, anaokulu ve ilköğretim okulları ile iletişim sağlanmalı, çeşitli proje ve işbirlikleri yapılmalıdır.

- Araştırmada da ortaya çıktı̆g üzere, fiziksel ve içerik özellikleri çocuklara uygun nitelikli kitaplar daha fazla okunmakta ve ödünç alınmaktadır. Bu tür kitapların kütüphanedeki görünürlükleri çeşitli yollarla artırılmalıdır. Bu kitaplara yönelik etkili, işlevsel, canlı sunumlar ve sergiler çocukların ilgisini çekecek, kitapların ödünç alınma sıklıklarını artıracaktır. Kütüphanede zaman zaman diğer kültürel etkinliklerle de birleştirilmiş/ilişkilendirilmiş çok yönlü tematik kitap tanıtımları yapılmalıdır.

Halk ve çocuk kütüphanesi dermelerinin çeşitli boyutlarıyla araştırılması, toplumun okuma kültürü için çaba göstermek anlamına gelmektedir. Gelişmiş ve güçlü çocuk kitapları dermeleri kütüphanelerin işlevlerini de güçlendirecektir. Gerçekleştirdiğimiz bu çalı̧̧a bir başka araştırma ile diğer il halk ve çocuk kütüphaneleri özelinde, onlarla karşılaştırılmalı olarak ya da dijital (elektronik) kaynakları da içerecek biçimde yapılabilir.

\section{Teşekkür}

$\mathrm{Bu}$ çalışmada verilerin elde edilmesi ve kitapların ödünç alınmasında anlayışlı yaklaşımı ve önemli yardımları için Eskişehir İl Halk Kütüphanesi Müdürü Sayın Mehmet Akkaya’ya; öntest ve kodlama aşamalarındaki anlamlı katkıları için yazar Sevim Ak, Nur İçözü ve Nihan Temiz'e; ayrıca Anadolu Üniversitesi Çocuk Gelişimi ve Eğitimi Bölümü Araştırma Görevlisi Gülhan Yılmaz Bursa ile kütüphaneci Günay Uysal, Asuman Nesibe Gök ve Nuran Akman'a çok teşekkür ederiz. 


\section{Kaynakça}

Alpöge, G. (2005, 11-12 Kasım). Okulöncesi kitapları ve çocuk edebiyatı [Bildiri]. Y. Çotuksöken ve N. Neydim (Yay. Hazl.), Çocuk ve İlkgençlik Edebiyatı Kurultayı, İstanbul, Türkiye (ss. 17-20) içinde. Maltepe Üniversitesi.

Altunışık, R., Çoşkun, R., Bayraktaroğlu, S. ve Yıldırım, E. (2010). Sosyal bilimlerde araştırma yöntemleri: SPSS uygulamalı. Sakarya Yayıncılık.

Aydın, S. (2019). Çocuk kütüphanelerinde nitelikli koleksiyon oluşturma ve geliştirme. A. Kakırman Yıldız (Yay. Haz.), Dünyanın iyiliği için çocuk kütüphaneleri (ss. 231-257) içinde. Hiperyayın.

Bakırcıŏglu, R. (2011). Çocuk ve ergende ruh sağlı̆̆l. Anı Yayıncılık.

Bassa, Z. (2013). Çocuk kitaplarında resimleme. M. Gönen (Yay. Haz.), Çocuk edebiyatı (ss. 179-221) içinde. Eğiten Kitap.

Birleşmiş Milletler Çocuk Haklarına Dair Sözleşme ve İhtiyari Protokoller, Usul Kuralları ile Çocuk Haklar1 Komitesi Genel Yorumlar1. (2006). UNICEF Türkiye. https://www.unicef.org/turkey/media/7941/file/ÇHDS\%20ve\%20İhtiyari\%20Protokoller,\%20U sul\%20Kuralları\%20ile\%20Çocuk\%20Hakları\%20Komitesi\%20Genel\%20Yorumları.pdf

Birleşmiş Milletler Çocuk Haklarına Dair Sözleşme. (1989). UNICEF Türkiye. https://www.unicef.org/turkey/\%C3\%A7ocuk-haklar\%C4\%B1na-dairs\%C3\%B6zle\%C5\%9Fme

Can, G. (2011). Gelişimin doğası. E. Ceyhan (Yay. Haz.), Erken çocukluk döneminde gelişim (Ünite 1) (ss. 1-24) içinde. Anadolu Üniversitesi.

Cengiz, E. (2017). Halk kütüphanelerinde derme gelisstirme politikalart: Türkiye'de halk kütüphaneleri üzerine bir değerlendirme [Yayımlanmamış yüksek lisans tezi]. Hacettepe Üniversitesi.

Cirhinlioğlu, F. G. (2010). Çocuk gelişimi ve ruh sağlı̆̆ı (2. bs.). Nobel Yayın Dağıtım.

Cüceloğlu, D. (1991). Insan ve davranışı (2. bs.). Remzi Kitabevi.

Çakmak Güleç, H. ve Geçgel, H. (2006). Çocuk edebiyatı (2. bs.). Kök Yayıncılık.

Çıng1, H. (1990). Örnekleme kuramı. Hacettepe Üniversitesi.

Çolaklar, H. (2019). Bartın İl Halk Kütüphanesindeki okul öncesi dönem çocuk kitaplarının dıș yapı ölçütleri: Yazım, dil, biçim ve içerik özelliklerine göre değerlendirilmesi. Bilgi Yönetimi Dergisi, 2(2), 145-168. https://doi.org/10.33721/by.643555

Dehart, G. B., Sroufe, L. A. ve Cooper, R. G. (2004). Child development it's a nature and course. McGraw Hill.

Demircan, C. (2006). TÜBİTAK çocuk kitaplığı dizisindeki kitapların dış yapısal ve iç yapısal olarak incelenmesi. Mersin Üniversitesi Ë̆itim Fakültesi Dergisi, 2(1), 12-27. https://dergipark.org.tr/tr/download/article-file/161002

Demirel, Ş. (2010). Çocuk edebiyatı. Ş. Demirel (Yay. Haz.), Edebi metinlerle çocuk edebiyatı (ss. 4582) içinde. Pegem.

Dewey, M. (1993). Dewey Onlu Sınıflama ve bağıntılı dizin: 20. basımın Türkçe çeviri ve uyarlaması (C. 2; F. N. Ayhan, Çev.). Milli Kütüphane Başkanlığı.

Dilidüzgün, S. (2013). Ana çizgileriyle çocuk ve çocuk edebiyatı (7. bs.). Z. Güneş (Yay. Haz.), Okulöncesinde çocuk edebiyatı (ss. 37-54) içinde. Anadolu Üniversitesi.

Dönmezler, E. (2019). Türkiye'de yayınlanmış 5-8 yaş resimli çocuk kitaplarının biçim, resim ve içerik açısından incelenmesi [Yayımlanmamış yüksek lisans tezi]. Mersin Üniversitesi.

Erbay, F. ve Aydoğan, Y. (2006, 4-6 Ekim). Okul öncesi çocuklar için hazırlanan resimli hikâye kitaplarının konu ve zaman kullanımı açısından incelenmesi [Bildiri]. S. Sever (Yay. Haz.), 2. 
Eskişehir İl Halk Kütüphanesi Dermesinde Bulunan Resimli Çocuk Kitaplarının Fiziksel ve İçerik Özelliklerinin Ödünç Alınma Üzerinde Etkisi

The Effect of Physical and Content Characteristics of Illustrated Children's Books in the Eskişehir Provincial

Public Library's Collections on Borrowing 381

Ulusal Çocuk ve Gençlik Edebiyatı Sempozyumu, Ankara, Türkiye (ss. 227-232) içinde. Ankara Üniversitesi.

Erkmen, N. (2017). Çocuk kütüphanelerinde en çok okunan çocuk kitaplarının çocuk edebiyatının temel ilkeleri bağlamında incelenmesi (Ankara ili örneği) [Yayımlanmamış yüksek lisans tezi]. Ankara Üniversitesi.

Eskişehir İl Halk Kütüphanesi. (2014). Hakkımızda. http://eskisehir.kutuphane.gov.tr/TR100380/hakkimizda.html

Gander, M. J. ve Gardiner, H. W. (1998). Çocuk ve ergen gelişimi (A. Dönmez, N. Çelen ve B. Onur, Çev.; 3. bs.). İmge Kitabevi.

Göknil, C. (1994). Okul öncesi çocuk kitaplarının özellikleri nedir? M. R. Şirin (Yay. Haz.), 99 soruda çocuk edebiyatı (ss. 138-150) içinde. Çocuk Vakfi.

Gönen, M. ve Aydos, E. H. (2016). Resimli çocuk kitaplarının içerik ve fiziki özelliklerinin incelenmesi. Siirt Üniversitesi Sosyal Bilimler Enstitüsü Dergisi, 1. https://dergipark.org.tr/en/pub/susbid/issue/17335/181022

Gönen, M. ve Veziroğlu, M. (2013). Çocuk edebiyatının genel hedefleri. M. Gönen (Yay. Haz.), Çocuk edebiyatı (ss. 1-12) içinde. Eğiten Kitap.

Halk Kütüphaneleri Yönetmeliği. (2012, 11 Ocak). Resmî Gazete (Sayı: 17789). http://www.kygm.gov.tr/Eklenti/5,halkkutuphaneleriyonetmeligi-11-01-2012-resmigazetepdf.pdf?0

IFLA [International Federation of Library Associations and Institutions]. (2003). Çocuk kütüphanesi hizmetleri için ilkeler (B. Yılmaz ve S. Ekici, Çev.). https://www.ifla.org/files/assets/libraries-forchildren-and-ya/publications/guidelines-for-childrens-libraries-services-tr.pdf

IFLA [International Federation of Library Associations and Institutions]. (2007). Guidelines for library services to babies and toddlers. https://www.ifla.org/files/assets/hq/publications/professionalreport/100.pdf

IFLA [International Federation of Library Associations and Institutions]. (2018). Guidelines for library services to children ages 0-18 (Revision of 2003 guidelines). https://www.ifla.org/files/assets/libraries-for-children-and-ya/publications/ifla-guidelines-forlibrary-services-to-children_aged-0-18.pdf

Kandır, A. (2007). Gelişimde 3-6 yaş. Morpa Kültür Yayınları.

Kaptan, S. (1998). Bilimsel araştırma ve istatistik teknikleri. Bilim Yayınevi.

Karataş, E. (2014). Çocuk edebiyatında "karakter" kavramı. Muğla Sttkı Koçman Üniversitesi Sosyal Bilimler Enstitüsü $\quad$ Dergisi, 33, 60-79. http://www.sobbiad.mu.edu.tr/index.php/asd/article/view/512/489

Karatay, H. (2007). Dil edinimi ve değer öğretimi sürecinde masalın önemi ve işlevi. Türk Ĕgitim Bilimleri Dergisi, 5(3), 463-477. https://dergipark.org.tr/tr/pub/tebd/issue/26115/275130

Kocabaş, İ. (1999). Çocuk kitabı seçim kriterleri ve 1997 yılını kapsayan bir değerlendirme [Yayımlanmamış yüksek lisans tezi]. Hacettepe Üniversitesi.

Koçak, M. (2017). 2000-2014 yılları arasında okul öncesi dönem çocukları için yayınlanmış olan hikâye kitaplarının dış yapı, iç yapı ve resimleme nitelikleri açısından incelenmesi [Yayımlanmamış yüksek lisans tezi]. Trakya Üniversitesi.

Kültür ve Turizm Bakanlığı Yayın Seçme Yönetmeliği. (2005, 18 Ağustos). Resmî Gazete (Sayı: 25849). https://teftis.ktb.gov.tr/TR-14506/kultur-ve-turizm-bakanligi-yayin--secmeyonetmeligi.html 
Kütüphaneler ve Yayımlar Genel Müdürlüğü. (2019). Halk kütüphaneleri 2019 yılı istatistikleri. https://kygm.ktb.gov.tr/TR-255535/2019-yili--istatistik-bilgileri.html

Levine, L. E. ve Munsch, J. (2019). Child development from infancy to adolescence. SAGE.

Miles, M. B. ve Huberman, M. A. (1994). Qualitative data analysis: An expanded sourcebook. SAGE.

Oğuzkan, A. F. (1983). Çocuk edebiyatı (3. bs.). Emel Matbaacılık.

Oktay, A. (1994). Çocuğun dil gelişiminin evreleri ile çocuk edebiyatı ilişkisinden söz eder misiniz? M. R. Şirin (Yay. Haz.), 99 soruda çocuk edebiyatı (ss. 167-170) içinde. Çocuk Vakfı.

O'Sullivan, E. (2010). Historical dictionary of children's literature. Scarecrow Press.

Polat, C. (2018). Halk kütüphanelerinde derme yönetimi: Politika ve ilkeler. Asiye K. Yıldız (Yay. Haz.), Halk kütüphaneleri: Geçmişten geleceğe yönelimler ve yeni roller (ss. 421-449) içinde. Hiperlink.

Santrock, J. W. ve Yussen, S. R. (1992). Child development (5. bs.). Wm. C. Brown.

Seven, S. (2010). Çocuk kitapları. Ş. Demirel (Yay. Haz.), Edebi metinlerle çocuk edebiyatı (ss. 105114) içinde. Pegem.

Sever, S. (1995). Çocuk kitaplarında bulunması gereken yapısal ve eğitsel özellikler. Abece Eğitim ve Sanat Dergisi, 107, 14-15. https://www.academia.edu/19830966/Cocuk_kitaplarinda_bulunmasi_gereken_yapisal_ve_egits el_ozellikler

Sever, S. (2013a). Resimli kitapların okulöncesi dönemdeki çocuğun gelişim sürecine katkısı (7. bs.). Z. Güneş (Yay. Haz.), Okulöncesinde çocuk edebiyatı (ss. 1-36) içinde. Anadolu Üniversitesi.

Sever, S. (2013b). Okulöncesi dönemdeki çocuklara seslenen kitaplarda bulunması gereken temel özellikler (7. bs.). Z. Güneş (Yay. Haz.), Okulöncesinde çocuk edebiyatı (ss. 55-71) içinde. Anadolu Üniversitesi.

Sever, S. (2017). Çocuk ve edebiyat. (9. bs.). Tudem.

Sever, S. (2018). Sanatsal uyaranlarla dil ögretimi. Tudem.

Sullivan, M. (2005). Fundamentals of children's services. American Library Association (ALA).

Svab, K. ve Zumer, M. (2015). The value of a library catalog for selecting children's picture books. $\begin{array}{llll}\text { Cataloging \& Classification } \quad \text { Quarterly, 53(7), } & \text { 717-737. }\end{array}$ https://doi.org/10.1080/01639374.2015.1044059

Şahin, G. (2014). Okul öncesi dönem çocuk kitaplarında görsel bir uyaran olarak resim. Journal of Turkish Studies, 9(3), 1309-1324. https://doi.org/10.7827/TurkishStudies.6507

Şirin, M. R. (2007). Çocuk edebiyatı kültürü. Kök Yayıncılık.

Şirin, M. R. (1994). Çocuk edebiyatı nedir? M. R. Şirin (Yay. Haz.), 99 soruda çocuk edebiyatı (ss. 933) içinde. Çocuk Vakfi.

Taşc1, E. (2019). 0-36 ay çocuklara yönelik resimli çocuk kitaplarının bir analizi [Yayımlanmamış yüksek lisans tezi]. Hacettepe Üniversitesi.

TDK [Türk Dil Kurumu]. (2019). Güncel Türkçe sözlük. https://sozluk.gov.tr/

Tuncer, N. (1994). Çocukların değişik yaşlarda ilgi duydukları konular ve bunları karşılayabilecek kitap türleri nelerdir? M. R. Şirin (Yay. Haz.), 99 soruda çocuk edebiyatı (ss. 198-202) içinde. Çocuk Vakfi.

Tunnel, M. O. ve Jacobs, J. S. (2008). Children's literature, briefly. Pearson.

Uludağ, M. E. (2010). Çocuk edebiyatında tema ve sevgi teması bağlamında anne ve baba sevgisi. Ş. Demirel (Yay. Haz.), Edebi metinlerle çocuk edebiyatı (ss. 83-88) içinde. Pegem. 
Eskişehir İl Halk Kütüphanesi Dermesinde Bulunan Resimli Çocuk Kitaplarının Fiziksel ve İçerik Özelliklerinin Ödünç Alınma Üzerinde Etkisi

The Effect of Physical and Content Characteristics of Illustrated Children's Books in the Eskişehir Provincial

Wei, C.-C. ve Ma, M.-Y. (2020). Designing attractive children's picture books: Evaluating the attractiveness factors of various picture book formats. The Design Journal, 23(2), 287-308. https://doi.org/10.1080/14606925.2020.1718277

Yenibaş, R. (2008). Çocuk gelişimi ĕgitimi ve să̆ğğg. İSMEK. https://ismek.ist/files/ismekOrg/File/ekitap/cocuk/COCUK.PDF

Yılmaz, A. ve Gönen, M. (2018, 14-17 Kasım). Halk kütüphanelerindeki resimli çocuk kitaplarının konu yönünden incelenmesi [Bildiri]. A. Kakırman Yıldız ve L. Özdemir (Yay. Hazl.), 1. Uluslararası Çocuk Kütüphaneleri Sempozyumu, Nevşehir, Türkiye (ss. 89-104) içinde. Kütüphaneler ve Yayımlar Genel Müdürlüğ̈. https://kygm.ktb.gov.tr/Eklenti/63324,1-uluslararasi-cocukkutuphaneleri-sempozyumupdf.pdf?0

Y1lmaz, B. (2019). Çocuk kütüphanesi hizmetleri kılavuzu. Hiperlink.

Yılmaz, O. (2016). Çocuk kitaplarında bulunması gereken özellikler. T. Şimşek (Yay. Haz.), Okul öncesinde çocuk edebiyatı ve medya (ss. 61-108) içinde. Grafiker. https://www.researchgate.net/publication/322224323_Cocuk_Kitaplarinda_Bulunmasi_Gereken _Ozellikler

EK 1. Eskişehir İl Halk Kütüphanesi Dermesi Resimli Çocuk Kitaplarını Değerlendirme Formu

\begin{tabular}{|l|l|l|}
\hline \multicolumn{2}{|l|}{ Bibliyografik Bilgiler ve Genel Özellikler } \\
\hline Kitap Sıra No: & \\
\hline B.1 & Eser adı & \\
\hline B.2 & Yazar adı & \\
\hline B.3 & Yayınevi & \\
\hline B.4 & Yayın yılı & $\ldots .$. \\
\hline B.5 & Kaçıncıi basıok $\square$ \\
\hline B.6 & Sayfa sayısı & \\
\hline B.7 & Özgün/Çeviri & Özgün $\square$ Çeviri $\square$ \\
\hline B.8 & Çeviren & Var $\square$ Yok $\square$ \\
\hline B.9 & Resimleyen & Var $\square$ Yok $\square$ \\
\hline B.10 & Yazar tanıtım sayfası & Var $\square$ Yok $\square$ \\
\hline B.11 & Resimleyen tanıtım sayfası & Var $\square$ Yok $\square$ \\
\hline B.12 & Sınıflama numarası & Belirtilmemiş $\square$ \\
\hline B.13 & Kitabın dermeye dâhil olduğu yıl & 0-3 yaş $\square$ \\
\hline B.14 & Yaş grubu & \\
\hline
\end{tabular}




\begin{tabular}{|c|c|c|}
\hline & & $\begin{array}{l}4-6 \text { yaş } \square \\
7+\text { yaş } \square \\
\text { Diğer } \square\end{array}$ \\
\hline B.15 & Kitabin boyutu & $\begin{array}{l}\text { Büyük }(22 \mathrm{~cm}+) \square \\
\text { Orta }(16-22 \mathrm{~cm}) \square \\
\text { Küçük }(12-15 \mathrm{~cm}) \square\end{array}$ \\
\hline B.16 & Kitabın biçimi & $\begin{array}{l}\text { Dikdörtgen } \square \\
\text { Kare } \square \\
\text { Diğer } \square\end{array}$ \\
\hline B.17 & Kitabın ciltlenmesi & $\begin{array}{l}\text { İplik } \square \\
\text { Tel } \square \\
\text { Yapıştırma } \square \\
\text { Diğer } \square\end{array}$ \\
\hline B.18 & Kitabın kapak türü & $\begin{array}{l}\text { İnce karton (kâğıt) kapak } \square \\
\text { Kalın karton kapak } \square\end{array}$ \\
\hline B.19 & Kitabın genel fiziksel durumu & $\begin{array}{l}\text { Yeni } \square \\
\text { Yıpranmış } \square \\
\text { Kullanılamayacak durumda } \\
\text { (parçalanmış) } \square \\
\text { Diğer (sayfaları eksik) } \square\end{array}$ \\
\hline B.20 & Kitabın yıllık ödünç alınma sıklığı & \\
\hline \multicolumn{3}{|c|}{ DIŞ YAPI ÖZELLİKLERİ } \\
\hline 1 & $\begin{array}{l}\text { Kitabın boyutu, hacim ve ağırlı̆̆ı yaş düzeyine } \\
\text { uygundur. }\end{array}$ & Evet $\square \quad$ Hayır $\square$ \\
\hline 2 & $\begin{array}{l}\text { Kitap her iki yana kolayca açılabilmekte ve açık } \\
\text { kalabilmektedir. }\end{array}$ & Evet $\square \quad$ Hayır $\square$ \\
\hline 3 & $\begin{array}{l}\text { Kâğıt kaliteli ve çocuğun göz sağlı̆̆ı açısından uygundur. } \\
\text { (Mürekkebin dağılmaması, mat olması, resim ve yazının } \\
\text { arka yüzeye çımaması). }\end{array}$ & Evet $\square \quad$ Hayır $\square$ \\
\hline
\end{tabular}


Eskişehir İl Halk Kütüphanesi Dermesinde Bulunan Resimli Çocuk Kitaplarının Fiziksel ve İçerik Özelliklerinin Ödünç Alınma Üzerinde Etkisi

The Effect of Physical and Content Characteristics of Illustrated Children's Books in the Eskişehir Provincial

\begin{tabular}{|l|l|r|}
\hline $\mathbf{4}$ & Kapağın görsel etkisi ilgi çekicidir. & Evet $\square \quad$ Hayır $\square$ \\
\hline $\mathbf{5}$ & $\begin{array}{l}\text { Kapak resmi kitabın konusunu (içeriğini) } \\
\text { yansıtmaktadır. }\end{array}$ & Evet $\square \quad$ Hayır $\square$ \\
\hline $\mathbf{6}$ & Cildi sağlamdır. \\
\hline $\mathbf{7}$ & Yazıların puntosu yaş düzeyine uygundur. \\
\hline $\mathbf{8}$ & $\begin{array}{l}\text { Harf renkleri, biçimleri ve satır aralıkları izleme ve } \\
\text { okuma rahatlı̆ı sağlamaktadır. }\end{array}$ & Evet $\square \quad$ Hayır $\square$ \\
\hline $\mathbf{9}$ & Sayfa düzenindeki resim-metin oranı uygundur. & Hayır $\square$ \\
\hline $\mathbf{1 0}$ & $\begin{array}{l}\text { Sayfa kenarlarındaki boşluklar, izleme-okuma rahatlığı } \\
\text { sağlamaktadır. }\end{array}$ & Hayır $\square$ \\
\hline $\mathbf{1 1}$ & Resimler ilgili metinle aynı sayfadadır. \\
\hline $\mathbf{1 2}$ & Resimler renklidir. & Hayır $\square$ \\
\hline $\mathbf{1 3}$ & Resimler, çocuğun öykü oluşturabileceği niteliktedir. & Hayır $\square$ \\
\hline $\mathbf{1 4}$ & Resimler hikâyeyi desteklemektedir. & Evet $\square \quad$ Hayır $\square$ \\
\hline $\mathbf{1 5}$ & Resimler metni doğru yansıtmaktadır. \\
\hline $\mathbf{1 6}$ & Resimler gerçekçidir. & Evet $\square \quad$ Hayır $\square$ \\
\hline $\mathbf{1 7}$ & Resimlerde korkutucu öğeler bulunmamaktadır. & Evet $\square \quad$ Hayır $\square$ \\
\hline $\mathbf{1 8}$ & Dil sade ve akıcıdır. $\square \quad$ Hayır $\square$ \\
\hline $\mathbf{1 9}$ & Kitapta eski ve yöresel dil kullanımın yoğun değildir. & Evet $\square$ Kıyır $\square$ \\
\hline $\mathbf{2 0}$ & Cümle yapmen $\square$ Hayırır $\square$ \\
\hline
\end{tabular}




\begin{tabular}{|c|c|c|}
\hline 21 & Yazım ve noktalama işareti hataları yoktur. & Evet $\square$ Kismen $\square$ Hayır $\square$ \\
\hline 22 & Cümlelerde argo sözcükler bulunmamaktadır. & Evet $\square$ Kismen $\square$ Hayır $\square$ \\
\hline 23 & $\begin{array}{l}\text { Tema çocuğun yaş grubuna uygundur (sevgi, dostluk, } \\
\text { kardeşlik vb.). }\end{array}$ & Evet $\square$ Kismen $\square$ Hayır $\square$ \\
\hline 24 & $\begin{array}{l}\text { Evrensel etik değerlere yer verilmiştir (eşitlik, } \\
\text { insan hayatına sayg1, doğaya sayg1, canlılara sayg1 vb. }\end{array}$ & Evet $\square$ Kismen $\square$ Hayır $\square$ \\
\hline 25 & Konusu didaktik değildir, düşündürücüdür. & Evet $\square$ Kismen $\square$ Hayır $\square$ \\
\hline 26 & $\begin{array}{l}\text { Konusu çocuğun günlük yaşamını ve deneyimlerini } \\
\text { kapsar. }\end{array}$ & Evet $\square$ Kismen $\square$ Hayır $\square$ \\
\hline 27 & Konunun olay örgüsü merak uyandırıcıdır. & Evet $\square$ Kismen $\square$ Hayır $\square$ \\
\hline 28 & $\begin{array}{l}\text { Hikâye umut ve iyimserlik duygusu verecek biçimde } \\
\text { sonuçlanmaktadır. }\end{array}$ & Evet $\square$ Kismen $\square$ Hayır $\square$ \\
\hline 29 & $\begin{array}{l}\text { Hikâye çocuğun kavram (soyut/somut, doğaüstü vb.) } \\
\text { dünyasına uygun yaşam durumları içermektedir. }\end{array}$ & Evet $\square$ Kismen $\square$ Hayır $\square$ \\
\hline 30 & $\begin{array}{l}\text { Hikâye çocuğu toplumsal yaşamdan ve gerçeklerden } \\
\text { uzaklaştırmamaktadır. }\end{array}$ & Evet $\square$ Kismen $\square$ Hayır $\square$ \\
\hline 31 & $\begin{array}{l}\text { Hikâye şiddet, ayrımcılık ötekileştirme öğeleri } \\
\text { içermemektedir. }\end{array}$ & Evet $\square$ Kismen $\square$ Hayır $\square$ \\
\hline 32 & $\begin{array}{l}\text { Hikâye çocuğa doğru ve yanlışlar konusunda } \\
\text { seçenekler sunmaktadır. }\end{array}$ & Evet $\square$ Kismen $\square$ Hayır $\square$ \\
\hline 33 & Hikâye çocuğa soru sordurmaktadır. & Evet $\square$ Kismen $\square$ Hayır $\square$ \\
\hline
\end{tabular}


Eskişehir İl Halk Kütüphanesi Dermesinde Bulunan Resimli Çocuk Kitaplarının Fiziksel ve İçerik Özelliklerinin Ödünç Alınma Üzerinde Etkisi

The Effect of Physical and Content Characteristics of Illustrated Children's Books in the Eskişehir Provincial Public Library's Collections on Borrowing

\begin{tabular}{|l|l|l|}
\hline $\mathbf{3 4}$ & $\begin{array}{l}\text { Kahraman, çocuğun özdeşim kurabileceği özelliklere } \\
\text { sahiptir (aynı zamanda hatalar yapabilen, iyiyle kötüyü } \\
\text { ayırabilen). }\end{array}$ & Evet $\square$ Kısmen $\square$ Hayır $\square$ \\
\hline $\mathbf{3 5}$ & $\begin{array}{l}\text { Kahramanlar çocuklar için olumsuz model } \\
\text { oluşturmamaktadır. }\end{array}$ & Evet $\square$ Kısmen $\square$ Hayır $\square$ \\
\hline $\mathbf{3 6}$ & Kitapta olaylar tutarlı bir şekilde ilerlemektedir. & Evet $\square$ Kısmen $\square$ Hayır $\square$ \\
\hline $\mathbf{3 7}$ & $\begin{array}{l}\text { Olaylar açık ve anlaşılır bir biçimde ilerlemektedir. } \\
\text { Evet } \square \text { Kısmen } \square \text { Hayır } \square\end{array}$ & Evet $\square$ Kismen $\square$ Hayır $\square$ \\
\hline $\mathbf{3 8}$ & $\begin{array}{l}\text { Kitap, çocukların gelişim düzeyine, ilgi ve } \\
\text { gereksinimlerine uygundur. }\end{array}$ & Kitap çocukta okuma isteği uyandıracak niteliktedir. \\
\hline $\mathbf{4 0}$ & Evet $\square$ Kısmen $\square$ Hayır $\square$ \\
\hline
\end{tabular}

